NOAA Technical Report NMFS SSRF- 675

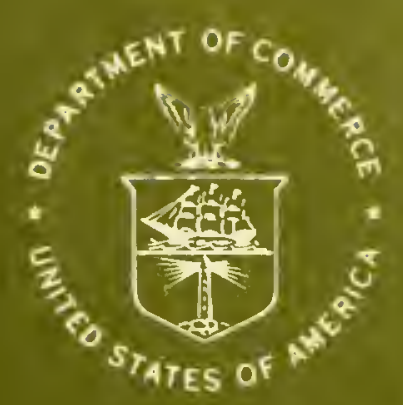

Proceedings of the

International Billfish Symposium

Kailua-Kona, Hawaii, 9-12 August 1972

Part 1. Report of the Symposium

RICHARDS. SHOMURA and FRANCIS WILLIAMS (Editors) 


\section{National Marine Fisheries Service, Special Scientific Report-Fisheries Series}

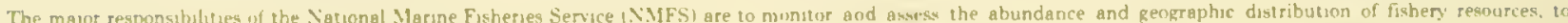

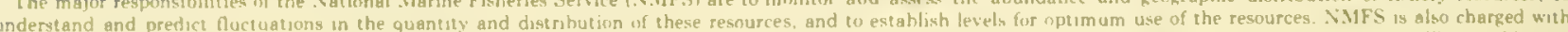

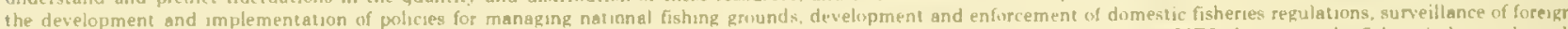

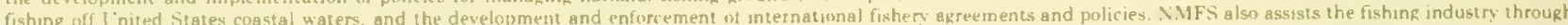

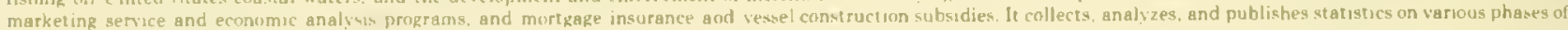
the industry

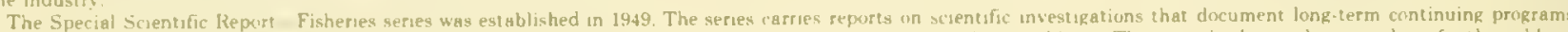

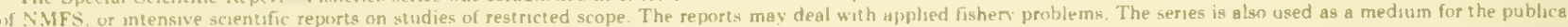
tion of biblographes of a specialized scientulic nature

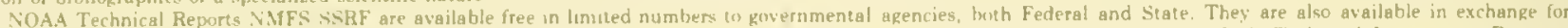

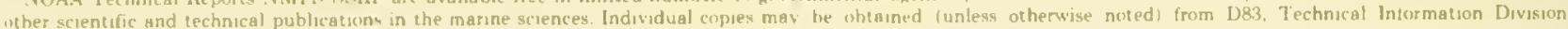
Ensirunmental science Information Center. NOAA, Washington. D.C. 20235 Recent SSRr"s are:

619 Macrozmiplankton and small nekton in the coastal waters oft Vancouver Island 1Canadal and Washington, spring and fall of 1963. By Donald S Day, January 1971. ui + 94 pp., 19 figs. 13 tables.

520. The Trade Wind Zone Oceanography Pilot Studv Part IX The sea-level wand theld and $w$ nd stress values. Julw 1 \% 33 to June 1965 . By Gunter R. Seckel June 19:0, $14+66$ pp.. 5 figs

t21 Predauon by sculpins on fall chunook salmon, Uncorhunchus eshoù scho. Iry uf hatchen urigin By Benjamin G. Patten Fehruary 19:1. 11 + It pp. 6 figs, 9 tables

622. Number and lengths, by season, of fishes caught with an otter trawi near Wiods Hole Massachuserts. September 1961 to December 196:2. By F E. Lux and F E. Nichy February 1971. $111+15$ pp. 3 figs. 19 tahles.

623. Apparent abundance, distributuon, and migrations of albacore. Thunnus alalungo. un the Jorth Pacutic langline grounds By Bran J Ruthschild and Marian Y Y Yong. september 1970. $v+37$ pp.. 19 figs.. 5 tahles

6.4 Influence of mechanical processing on the quality and yeld of bay scallop meats B. N B. Wiehh and F. B Thomas. April 1971, .11 + 11 pp., 9 fixs, 3 eables.

6.5. Distribusion of salmon and related oceanomeraphic features in the Xorth Pacitic Ocean spring 1468 By. Rubets R French Ruchard G Bakkala, Masanao Osako, and Jun Lo .1arch 1971. 11 $+22 \mathrm{pp} .19$ ligs.. 3 (ables

6.ti Commercial fisher and biolugy of the ireshwater shrump. Mocrabrachum, in the Liwes Si Paul River Laheria, 1952-53. Bv George C Milter Fehruarv 1971 11 + 13 pp.. \& figs, itables.

62: Calıco scatlops of the Southeastern ("nited States, 1959.69 By Rohert Cummins. Jt lune 1971. in + in' pp 23 figs 3 tahles.

120 Fur Seal Investugatıns, 1969 Br. NMFs Marine . Mammal Buologica! Lahoratory Aupust 1971 a pp.. 20 figs, 4 tables, 23 appendix A tables, 10 appendix B tables

629 Analysis of the operations of seven Hawallan skipjack tuna fishing vessels. June

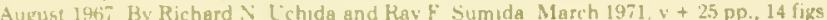
21 tahles. For sale by the Superintendent of Documents. ('S Government Printing Ot. Iice. Hashington, D C. 20402

630) Blue crab meat. 1. Preservation hv treezang fuly 1971, u +13 pp.. 5 fizs., 2 tahles. If Effect of chemical treatments un acceptalis ity. Bv. Jurgen $H$. Strusser. Jean S. Lennon. and Ërederick \& king Julv 1971 , 11i +12 pp 1 tup 9 tables.

631 Occurrence of thiaminase in some common aquaric anımals of the linsted State:

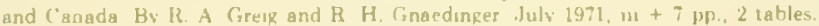

Fis An annotuted hiblukraphy of attempts to rear the larvae of marne lishes in the

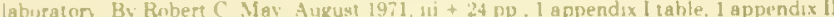
tahle fir sale by (he superintendent of 1) wcuments. (') G Guvernment Printing Outice. Washington. B.C 20402

hill Blueing of processed crah meat II Identification of wme lactors involved in the hlue discoloration uf canned crab meat Callinectess sopsdus Bv Melvin E. Watera Mav $1971111+\cdots$ pp. 1 fig. 3 tahles

6. I Ake composition. weight. Jength, and sex of herring (I I peo pollcsist, used for, reclut

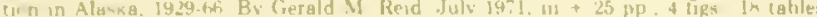

Q35. A biblugraphy of the blackein tung. Thurnus otlantucus (Lesson) Bv Grant L Beardslev and David C Simmons. August 1971, $10 \mathrm{pp}$. For sale by the Superintendent of Documents, C' S. Guvernment Printing Office, Washington, D.C 20402.

636 Oil pollution on Wake Island from the tariker $R \quad C$ stoner By Reginald $M$ (imoding Mas 19:1 14 12 pp. \& figs. 2 tables. For sale by the Superintendent of Documentw I' Gi Guertment Pringing Office, Washington, Do 20402

Q37 Occurrence of larval. Juvenile, and mature crabs in the vicinity of Beaufort Inlet.

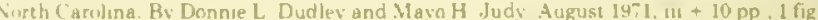
5 lables fror saie by the Superinterident of Documents l'S Government Printinz Office. Washington. DC 20402

63x Length-wetght relations of haddock from commercial landings in Siew England. 1931.55. By Bradford E Briwn and Richard C. Hennemuth. August 1971, v + 13 pp., 16 figs, 6 tables, 10 appendix A tables For sale by the Superintendent of Documents, $L S$ Governnent Printing Office. Washingtan. D C. 2040?

639 A hydrographic surey ni the Galveston Bayalstem. Texas 1963-f6. B. E.J. Pullen. IV. L Trent, and (; B Adams Octoher 19"1 $y+13 \mathrm{pm} 15$ figs litables For sale by the superintendent of Documents. I'S Government Printing Office. Washungton. D 20402

Gil) Annotated hiblingraphy in the fishng industry and biology of the blue crah. Collinerles sopldu. By Marlin F. Tagalz and Ann Bowman Hall. Aurust 1971.94 pp For sale by the Superintendent of Dncuments, I'S. Goxernment Printing Otfice. Washingtun. DC 204112

641. Tse of threadfin shad. Dori somo petenense, as live bat during experimental mole and line lishing for skupjack cuna. Korvuunus pelamis, in Hawail. By Robert T B lwersen August 1971,111 +10 pp. 3 figs. T tables For sale by the iuperintendent of

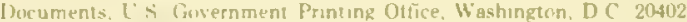

64:2 Atiantic menhaden Bret ourta tsrannus resource and fisherv analssis of decline B. Kenneth A Henry Augusi 1971. $\%+32$ pp.. 40 figs. 5 appendix ligs. 3 tables. uppendix tahles. Fur sale hy the Superintendent of Documents, L"s Government Printing Office. Washington. D.C 30402

643. Surtace winds of the routheaseren tropuc al Atlanus Ocean By John M siteigner and Mertun C Ingham Octuber $1971,13+20$ pp.. 17 ligs for sale by the Superintendent of 1)ecuments. I S Grwernment Prineng Oftice. Washington, D.C 20402

bits lahihituin of thewh hrowning and skin color fading in frozen fillets of yellowev snapper (Lutzanus uonus) By Haruld C. Thompuon. Jr, and Mary H Thompson. Fehruary 197.2, $111+6130$. 3 tables. For sale by the superintendent of locuments, ( 5 . (iwvernment Printing Office. Washingtun. D.C 20402

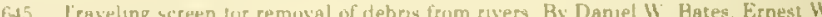
Murphey, and Martin G Beam. October 1971 it $+6 p p$, 6 figs, I lahle For wale hy the

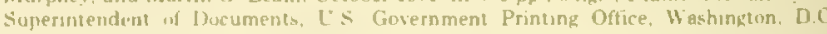
$2(2)+2$

64ti Disuls d natrogen concentratuons in the Columbia and Snake Rivers in 1970 and

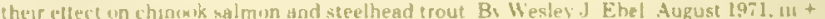

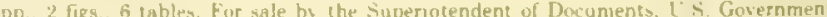
Prontıng Ortice, Washıngtun. D C 20403

iit T Rerused annulatect hat of parauten from sea mammals caught off the weal coast of

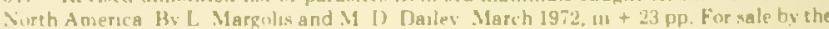
supersntendeat of Dencuments. I i Civernment Pronting Office, Washingtun, DC (2) 4112 
NOAA Technical Report NMFS SSRF-675

\title{
Proceedings of the \\ International Billfish Symposium
}

Kailua-Kona, Hawaii, 9-12 August 1972 Part 1. Report of the Symposium

\author{
RICHARD S. SHOMURA and FRANCIS WILLIAMS (Editors)
}

SEATTLE WA

March 1975

UNITED STATES

DEPARTMENT OF COMMERCE

Frederick B. Dent, Secretary

For sale by the Superintendent of Documents, U.S. Government

Printing Office, Washington, D.C. 20402
National Marine

Fisheries Service

Robert W Schoning. Director 
The National Marine Fisheries Service (NMFS) does not approve, recommend or endorse any proprietary product or proprietary material mentioned in this publication. No reference shall be made to NMFS, or to this publication furnished by NMFS, in any advertising or sales promotion which would indicate or imply that N.MFS approves, recommends or endorses any proprietary product or proprietary material mentioned herein, or which has as its purpose an intent to cause directly or indirectly the advertised product to be used or purchased because of this NMFS publication. 


\section{CONTENTS}

Dedications

General report

Introduction

Background

Opening session

Officers and organization of work

Officers of the Symposium

Organization of work

Sectional reports

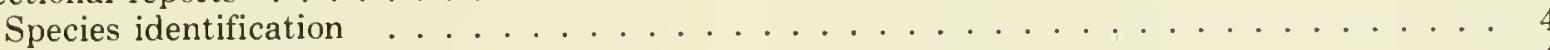

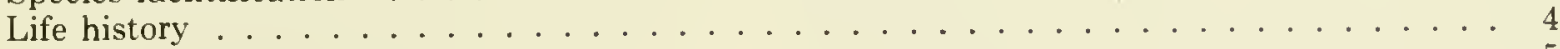

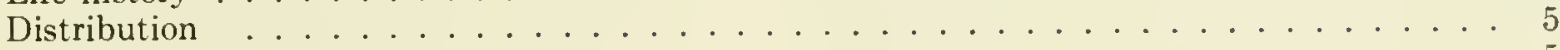

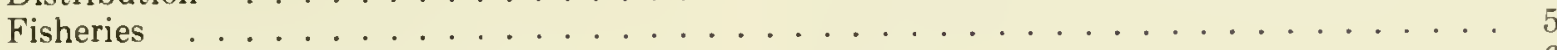

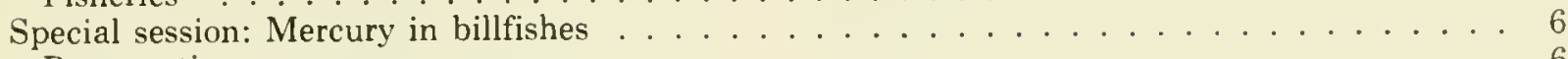

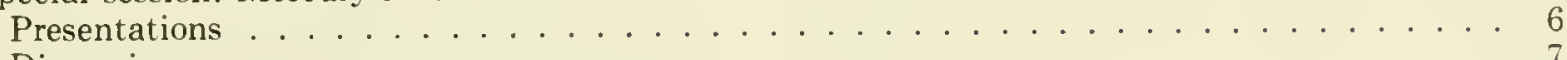

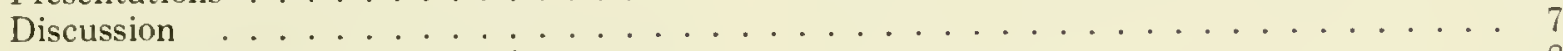

Special session: Sportsmen-scientists . . . . . . . . . . . . . . . . . 8

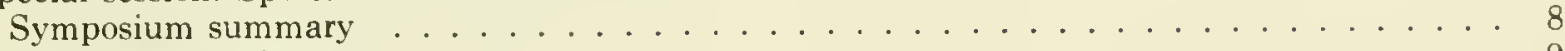

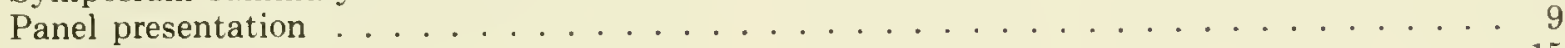

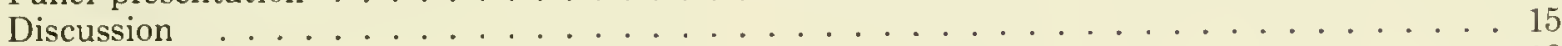

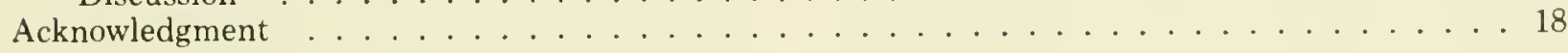

\section{Annexes}

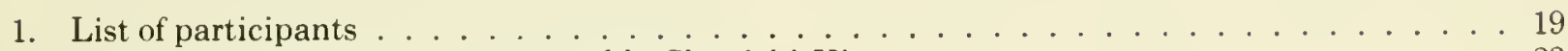

2. Welcoming address by the Honorable Shunichi Kimura . . . . . . . . . . . . . 23

3. Opening address by Philip M. Roedel . . . . . . . . . . . . . . . . . . 24

4. Address by Michio Takata . . . . . . . . . . . . . . . . . . . . . 26

5. Address by J. Thomas Stuart III . . . . . . . . . . . . . . . . . . . . . . 26

6. Address by Peter Fithian . . . . . . . . . . . . . . . . . . . . 27

7. Text of cable from F. E. Popper . . . . . . . . . . . . . . . . . . . 27

8. Potential health hazards of mercury in fish by Albert C. Kolbye . . . . . . . . . . . . 28

9. Status of mercury studies in Hawaii by Richard A. Marland . . . . . . . . . . . . 30

10. Definitions and methods of measuring and counting in the billfishes (Istiophoridae, Xiphiidae)

by Luis Rene Rivas . . . . . . . . . . . . . . . . . . . . . . 31 


\section{DEDICATIONS}

\section{Oscar Elton Sette}

1900-1972

\section{John K. Howard \\ 1891-1965}

John K. Howard was an outstanding example of a man whose interest in ocean science led to a second career after retirement from law practice. His many friends throughout the world remember his great enthusiasm, combining a passion for sport fishing with a desire to increase our knowledge of the biggame fishes, in particular the billfishes. He sponsored and directed a research program at the Institute of Marine Science, University of Miami, and also gave much logistic aid to ichthyologists around the world. His travels took him to East Africa, Australia, New Zealand, and Japan. He also visited Portugal, Spain, and Italy, where he collected large numbers of spearfish and white marlin in an attempt to solve the specific identity of the Mediterranean spearfish.

Shortly before his death he completed, with Dr. Shoji Ueyanagi of Japan, a large report on the seasonal and geographic distribution of billfishes in the Pacific Ocean. His similar work on these fishes in the Indian Ocean was completed by Dr. Walter A. Starck II.

John K. Howard was born in Paris, France, on 4 April 1891. He received his undergraduate degree from Harvard College in 1915 and his law degree from Harvard College in 1917. After retiring from law practice he studied ichthyology at the University of Miami. He served in both World Wars as an army officer, achieving the rank of colonel.

\begin{abstract}
Dr. Sette's contributions to fisheries science are manifold and cover more than half a century of active work as a fishery biologist and administrator.

From 1949 to 1955 he acted as chief of the newly established Pacific Oceanic Fishery Investigations (POFI), a Honolulu-based research facility of the Fish and Wildlife Service, U.S. Department of the Interior (presently the Honolulu Laboratory of the Southwest Fisheries Center, National Marine Fisheries Service, NOAA, U.S. Department of Commerce). Here he was responsible for the development of a high-seas fisheries program in the central Pacific Ocean, a program that laid the groundwork for much of what is known today of the tunas, sharks, and billfishes of this expansive body of water. Although much of the research effort of his staff at POFI was devoted to tunas as the principal pelagic species of commercial interest, Dr. Sette was among the first to recognize the need to study the full spectrum of the food web in order to understand the various biological resources of the ocean. The research on billfishes undertaken during and after his tenure in Honolulu is a result of his appreciation of the need to collect data from all levels of the ecosystem. Dr. Sette was also one of the first to advocate integrating the field of biology with those of oceanography and meteorology.
\end{abstract}

Oscar Elton Sette was born in Clyman, Wis., on 29 March 1900. In 1910 his family moved to southern California, where he completed his intermediate and high school education. He received his Bachelor of Arts degree from Stanford University in 1922, a Master's degree in Biology from Harvard University in 1930, and a Doctorate in Biology from Stanford University in 1957.

During a career which extended over 50 years, Dr. Sette served in various research and administrative capacities with the California State Fisheries Laboratory, and the National Marine Fisheries Service and its predecessor agencies. Beginning in 1924 with the U.S. Bureau of Fisheries, he held positions as Chief, Division of Fishery Industries in Washington, D.C.; Chief of the North Atlantic Fishery Investigations; Chief of the South Pacific Fishery Investigations; Chief, Pacific Oceanic Fishery Investigations; and Director, Ocean Research Laboratory, on the campus of Stanford University.

De. Sette "retired" in 1970, but continued his research as an "annuitant" employee of the Federal Government until his death in July 1972. 


\section{GENERAL REPORT}

\section{Introduction}

The Symposium was sponsored by the National Marine Fisheries Service (NMFS) of the National Oceanic and Atmospheric Administration, U.S. Department of Commerce, and was held at KailuaKona, Hawaii, from 9 to 12 August 1972. The Symposium was cosponsored by the County of Hawaii, the Hawaii State Division of Fish and Game, the Marine Affairs Coordinator of the State of Hawaii, and the Hawaiian International Billfish Tournament (HIBT). The Food and Agriculture Organization of the United Nations (FAO) also actively supported the Symposium.

\section{Background}

Since the mid-1960's the pelagic waters of the world's oceans extending from about lat. $40^{\circ} \mathrm{N}$ to $40^{\circ} \mathrm{S}$ have been fished with longline gear for fish species of commercial importance. The principal species sought have been the tunas; thus, these pelagic fishes have received considerable attention from biologists and fishery administrators. Tunas have been the subject of discussions at the Scientific Meeting on the Biology of Tunas and Related Species held in La Jolla, Calif., 2-14 July 1962; the Symposium on Scombroid Fishes held in Mandapam Camp, India, 12-15 January 1962; and the Governor's Conference on Central Pacific Fishery Resources held in Hawaii, 28 February-12 March 1966. Further, those tuna species of commercial importance have been the focus of attention in recent years and have been the subject of review at annual international meetings, e.g., Inter-American Tropical Tuna Commission (IATTC) and International Commission for the Conservation of Atlantic Tunas (ICCAT), and domestic meetings, e.g., Pacific Tuna Conferences.

Unlike the tunas, the other major group of pelagic fishes taken by longline gear-the billfishes-has received very little attention. The relatively large size attained and the difficulty in obtaining adequate numbers of specimens for examination have kept our knowledge of billfishes to a low level. Studies undertaken by individual scientists have been based on few specimens, specimens principally collected at the centers of sport fisheries. Access to data and specimens collected by the extensive longline fisheries has been limited primarily because the accommodations aboard commercial longline vessels are limited and fishing trips generally extend over periods of several months. The principal reason for this restricted information, however, has been the lack of urgency and priority expressed by administrators of the major fishing countries.

During the past 5 or 6 yr the need to assess the status of stocks of the various species of the billfishes has become apparent. This has been reflected in the concern expressed by sport fishermen throughout the world regarding the declining catches of billfishes and the increased importance of billfishes noted by the commercial interests. The sport fishery catch rates of sailfish in the Pacific waters off Mexico have declined dramatically in the last decade. This decline has been attributed to the intensive longline fishery which started in 1963.

In 1970, NMFS held a workshop at the Tiburon Fisheries Laboratory to: 1) review briefly the available background knowledge of billfish biology, 2) evaluate data relating to the assessment of billfish resources, and 3) explore the types of cooperative research needed in order to accomplish objectives outlined in 1) and 2).

In order to highlight their importance, a special session on billfishes was held at the $22 \mathrm{~d}$ Tuna Conference (October 1971) at Lake Arrowhead, Calif. At the conference a series of papers presented on billfishes again reiterated the need for a major symposium to bring together all known information on the subject.

On the basis of these preliminary meetings, NMFS decided to sponsor an international billfish symposium. This was to be the first major symposium organized by the newly created NMFS. In selecting a location for the symposium, the organization committee decided to hold it in conjunction with the HIBT, which is held annually at Kailua-Kona, Hawaii. This joint arrangement had the advantages of 1) having available at the symposium sport fishermen from a number of countries, and 2) permitting billfish specimens to be made available to scientists for research purposes.

\section{Opening Session}

Mr. Richard S. Shomura, Cochairman of the Symposium, called the meeting to order and introduced the Honorable Shunichi Kimura, Mayor of the County of Hawaii. Mayor Kimura in his address welcomed the Symposium participants to the Island of Hawaii. He stressed that in developing the islands' resources there is a need for a well balanced mix of indigenous basic industries and scientific research in complementary disciplines. Mayor Kimura mentioned how appropriate in this respect were some of the research projects located on Hawaii, such as those in tropical agriculture, astronomy, geothermal energy, volcanology, and atmospheric sciences. He was delighted that fisheries expertise, in the form of the Symposium and its participants, had come to KailuaKona where sport fishing, especially the annual HIBT, is such a valuable part of the recreational and tourist activities.

Mr. Shomura then introduced Mr. Philip M. Roedel, Director, NMFS. Mr. Roedel, in his opening

'See Annex 2 
address $^{2}$, brought greetings from Dr. Robert $M$. White, Administrator of the National Oceanic and Atmospheric Administration. This was the first scientific symposium organized by NMFS since its formation in October 1970. The two primary reasons for holding the Symposium were 1) scientific studies of billfishes on a global scale were very limited, and 2) it would provide a forum for interactions between sport fishermen and scientists with regard to a high-seas fishery. Mr. Roedel noted that notwithstanding the long recognized importance of billfishes in worldwide sports and commercial fisheries, we have very little idea of the size of the resource. Published data on the various species are sparse and scattered, and much in Japanese, and thus the Symposium Proceedings would provide the basic background information essential for further detailed studies of the billfishes. Though there are considerable biological, socioeconomic, and politico-legal problems to be solved with regard to billfishes, they are included in only one international group concerned with management, i.e., the ICCAT. Mr. Roedel referred to the occurrence of heavy metals in billfishes and the intense public interest in this aspect, which had prompted the special symposium evening session on the subject. In conclusion, he noted the success of the various cooperative programs between sport fishermen and scientists, especially in tagging, which is important in migration studies of billfishes.

Further addresses ${ }^{3}$ of welcome were made by Mr. Michio Takata, Director, Hawaii State Division of Fish and Game, Mr. J. Thomas Stuart III representing Dr. John P. Craven, Hawaii State Marine Affairs Coordinator, and Mr. Peter S. Fithian, Chairman, Board of Governors, HIB'T. Mr. Shomura then read the text of a cable received from Mr. F. E. Popper, Assistant Director-General, Department of Fisheries, Food and Agriculture Organization of the United Nations, Rome, Italy.

Dr. F. Williams, Symposium Cochairman, in opening the scientific part of the Opening Session indicated that the intention of the organizing committee was to commence with comprehensive and up-to-date reviews, on a worldwide basis, of the commercial and sport fishing fisheries activities for billfish. The two scientists chosen for this task, respectively Dr. Shoji Ueyanagi and Dr. Donald P. de Sylva, are experts in these fields and share a common linkage with the late John K. Howard with whom they worked closely. Dr. Williams then introduced the speakers, whose presentations are given in full in Part 2 of the Proceedings.

In his review of the commercial fisheries for billfishes, Dr. Ueyanagi stated that the present world production of billfishes is approximately 100,000 tons

\footnotetext{
${ }^{2}$ See Annex 3.
}

'See Annexes 4, 5, and 6.

'See Annex 7. per year, of which more than $90 \%$ is taken by the tuna longline fishery. Japan alone produces about $70 \%$ of the world's catch of billfishes and is the principal consumer nation of these fish.

Although billfishes account for only about $18 \%$ of the longline catches, they are presently of considerable importance, especially among the fishery products utilized in Japan. Dr. Ueyanagi discussed the value and utilization of billfishes in Japan and described how billfishes have gained status as a quality fish, commanding prices comparable to the tunas. In addition, he described the expansion of the longline fishery, showing that by 1965 the fishery had covered the entire distributional range of the billfishes. Catch and effort data for billfishes indicate that swordfish is the only species which has shown an increase in landings in recent years; blue marlin landings have decreased in the South Pacific, Atlantic, and also, to a slightly lesser degree, in the Indian Ocean, while the catch of the striped marlin has fluctuated greatly from year to year.

Dr. de Sylva stated that sport fishing for billfishes takes place in nearly all warm waters, primarily in tropical and subtropical seas. In probable descending order of relative abundance, the principal species caught by anglers are: sailfish, white marlin, blue marlin, striped marlin, black marlin, swordfish, and spearfish. He then indicated the areas of the world ocean where the most important sport fisheries are presently located. In some regions maximum angling effort coincides with maximum availability of billfish, while in other regions, especially in the western North Atlantic Ocean, Dr. de Sylva stated that maximum angling pressure is correlated with angling tournaments which in turn relate to summer vacations and the tendency of most anglers to fish only during good weather. Angling for billfish during the "off season" may well produce good results in areas which are heavily fished only at certain periods. It seems likely that new billfishing regions can be developed, but this requires the assistance of local governments to provide or insure adequate sport fishing vessels, docks, bait, and, especially, qualified captains and crew.

Dr. de Sylva believes that the relative inefficiency of the gear used by anglers to catch billfish makes it unlikely that angling can seriously deplete the stocks, other factors such as natural environmental fluctuations, pollution, or commercial fishing being equal. There is little evidence that commercial fisheries are seriously affecting the sport catches. An exception is in the eastern Pacific Ocean, where the mean size of sailfish and striped marlin has decreased; these decreases may be attributed to heavy commercial fishing pressure from longline fleets.

The economic value of the billfish sport fishery is extremely important to local communities which support angling activities. In spite of some conservationist feelings promoting release of billfish which are not tagged, Dr. de Sylva noted that catches could 
be retained for human consumption without seriously depleting the stocks, thus further contributing to local economics.

\section{Officers and Organization of Work}

\section{Officers of the Symposium}

Cochairmen:

Richard S. Shomura

F. Williams

Sectional Officers:

Section 1. Species Identification

Chairman: William J. Richards

Rapporteur: Izumi Nakamura

Section 2. Life History

Chairman: C. Richard Robins

Rapporteur: Eugene L. Nakamura

Section 3. Distribution

Chairman: Nigel Merrett

Rapporteur: Witek Klawe

Section 4. Fisheries

Chairman: Shoji Ueyanagi

Rapporteur: James S. Beckett

Special Session:

Mercury in Billfishes

Chairman: Peter S. Fithian

Rapporteur: John Baxter

Panel Members: James S. Beckett

Albert C. Kolbye, Jr.

Richard E. Marland

Richard S. Shomura

Cynthia D. Shultz

Special Session:

Sportsmen - Scientists

Symposium Summary: Frank J. Hester

Panel Discussion

Chairman: Dudley C. Lewis

Rapporteur: Peter S. Fithian

Sportsmen: Peter Goadby

George Parker

Richard H. Stroud

Scientists: William L. Craig

C. Richard Robins

James L. Squire

Secretariat:

\section{Robert Bonifacio \\ Robert T. B. Iversen \\ Marjorie C. Siu}

Organization of Work.-Following the overview papers on commercial and sport fishing activities for billfishes given at the opening session, the Symposium was organized into four sections and two special sessions. The sections covered the fields of 1) Species Identification, 2) Life History, 3) Distribution, and 4) Fisheries. There were 6 papers contributed in Section 1, 13 in Section 2, 10 in Section 3, and 7 in Section 4. A discussion period concluded the presentation of the papers in each section. The first of the special sessions was devoted to consideration of the problems related to the mercury level in fishes and consisted of both formal presentations and a questionand-answer period open to the public. The second of the special sessions was a forum for the exchange of views between sport fishermen and scientists held at the end of the Symposium. It commenced with a summary of the scientific sessions of the Symposium, followed by informal presentations on various billfish topics by a mixed panel of sportsmen and scientists. A subsequent extensive discussion period was open to all.

\section{Sectional Reports}

Species Identification.-At this session six papers were presented covering various aspects of the identification of billfishes from young stages through adults, including the fossil record of these fishes. The fossil record is rather scant, with most of the material consisting of fossilized bills. Additional research in this area of study will add greatly to our knowledge of the phylogenetic relationships of these animals.

The identity of adults is quite well understood at this time with the exception of the so-called "hatchet marlin" which occurs in the Atlantic and possibly the Pacific Ocean. Evidence was presented that Tetrapturus georgei is a valid species in the Atlantic Ocean. The question of whether or not the blue marlins and the sailfishes in the Atlantic and Indo-Pacific Oceans are distinct species, subspecies, or subpopulations is still unresolved, as is the presence of black marlin in the Atlantic Ocean. Research in the sea area off the tip of South Africa should resolve some of these problems.

Three papers on the identity of the young stages of billfishes emphasized the need for further research, especially the study of variations in morphology. Data were also presented on additional characters which are useful in the separation of the young of IndoPacific species. Fruitful avenues for future research were suggested. These included a need for additional material, particularly small juveniles, and a need to rear these animals in the laboratory. The young stages of swordfish are quite well understood and present no problems.

In conclusion, the absence of information on the anatomy of all life stages and of the eggs of istiophorids was commented upon. Further it was stressed that the scientific nomenclature and the common names for these species should remain stabilized and not be allowed to fall into disarray.

Life History.- Thirteen papers were presented in the session on life history. Four papers dealt with the general biology of billfishes: the Atlantic blue marlin around Jamaica (not included in Part 2); the Atlantic sailfish off south Florida; billfishes in the eastern tropical Pacific Ocean; and swordfish in the northwest Atlantic Ocean. Another paper discussed present and 
future research on billfishes in Australia and New Zealand (abstract only, in Part 2). Three papers dealt with morphology: morphometrics of eastern Pacific billfishes; length-weight data of western Atlantic billfishes; and length-weight relations of central Pacific billfishes. Two papers were presented on mercury content in billfishes: one on northwest Atlantic swordfish and the other on billfishes from Hawaii and southern California. The remaining three papers dealt with various aspects of life history: food and feeding habits of swordfish in the northwestern Atlantic Ocean; maturation and fecundity of Hawaiian swordfish; and gastric ulcers in blue marlin and black marlin from Hawaii.

The papers, and the questions and discussions following the papers, reinforced the belief of biologists that although several aspects of the biology of billfishes are now known, much more must be learned. The life history of any one species is far from being completely known.

Much data have been obtained in the past from taxidermists. The bias of using such data for certain types of studies, such as growth, was explained.

Two papers referred to parasites. The existence of substantial literature on parasites of billfishes was pointed out, along with a need to collate this material.

Attempts at aging billfish by counting rings of hard parts such as spines was reported for Atlantic sailfish and Atlantic swordfish, but no success had yet been attained owing to the inability to determine what length of time a single ring represented.

Pollution was mentioned as a possible factor in decreased sailfish catches off south Florida. Sailfish occur closer inshore than other species of billfishes, and thus could be seriously affected. This was the only time pollution was mentioned.

Distribution.-During this section of the Symposium it became apparent that many facets of research on istiophorids and xiphiids are of interest, not only to the billfish biologists but also to a much wider scientific community. One report contained information which should be of particular interest to zoogeographers; another was concerned with oceanographic studies directed primarily towards billfish biology. In the latter study ocean temperatures were monitored by means of an airborne infrared sensor, and the data obtained proved to be of immediate use to meteorologists, environmental engineers, and other scientific and technical groups.

The Symposium audience was pleased to hear repeatedly just how much the sportsmen have been able to help the scientists. Billfish tagging illustrates this very well. A great deal has been learned about billfishes from recapture of marked fish. Although most of the billfish tagging has been done by sportsmen, the commercial fishery's role in tagging operations cannot be overlooked. Activities of the latter is limited mainly to tag returns, including accompanying data on the fish. Perhaps more billfish could be tagged during commercial operations; this possibility deserves attention from fishery biologists. During the presentation of reports, as well as during the discussion periods, some concern was expressed as to the need for careful planning prior to a tagging program. This is to assure not only maximum inflow of recapture data, but also inflow of data which would definitely aid in analysis of the movements and growth of the fish. An obvious need for better tags, perhaps more sophisticated tags, and better tagging techniques was stressed by several of the speakers. For example, incorporation of tetracycline, lead chelate, or some other compound in the tag could be used to mark time in the bones of the tagged fish and thus aid in age and growth studies by means of hard parts. Most of the participants were greatly impressed with the type of information which results from tracking billfish tagged with the sophisticated "sonic" device described by one speaker.

Billfish larvae caught during various scientific cruises provide us with valuable information of the spawning habits of the adults, as well as on the early life history of the istiophorids and xiphiids. Larval studies are hampered by the considerable difficulties encountered in separating the various billfish species. The only exception is the swordfish which, even at a very early life stage, can be separated readily from the other billfishes. The problem of identification of the billfishes is so great that at the conclusion of this Symposium a 2-day workshop to treat this subject will be held in Honolulu and be attended by several larval billfish experts (Working Party on the Early Life History of the Billfishes of the FAO Panel of Experts for the Facilitation of Tuna Research).

The problem of evaluating the fishing effort related to the sport fishery catch was raised. This is a difficult problem and will be discussed in the following session.

Fisheries.-The papers presented in this section dealt mainly with descriptive accounts of specific fisheries, e.g., the sport fishery in the northeastern Gulf of Mexico, the commercial longline fishery in Hawaii, and the commercial fisheries of Taiwan, and with the presentation and analyses of catch statistics. From the results presented it became apparent that major gaps in our knowledge of billfish biology and population dynamics exist, particularly with regard to age and growth, mortality rates, and stock structure.

One paper specifically examined the in. terrelationship of the environment and the distribution of striped marlin.

On the basis of data collected to date, much of what we know today of the time and space distribution of billfishes is based on catch statistics collected by the longline fisheries prosecuted by Japan, South Korea, and Taiwan. In addition to being far-ranging, the gear used by the various longline fisheries is essentially the same; thus, the indices of abundance are comparable. This comparability of data was not found to be true 
for the data collected by the sport fisheries. In the discussion that followed this session, it was recognized by participants that although the sport fisheries for billfishes represents a rich source of good data, biologists are not fully utilizing this source. With a few exceptions, the kinds of catch and effort data collected by individual fishermen, sport fishing clubs, and biologists vary so widely that the data cannot be pooled. One shortcoming noted in sport fisheries data is the lack of recorded zero catches. The importance of this information was discussed in some detail. The need to standardize the collection of billfish statistics from sport fisheries was apparent.

Although the billfish landings in some areas, e.g., Taiwan, showed increases in recent years (possibly reflecting increased effort), the general trends for the several species of billfishes noted in the catch statistics of the commercial and recreational fisheries are downward. In the eastern Pacific Ocean the decline in apparent abundance was especially noted for sailfish. The catch rate dropped from 80 fish per 1,000 hooks in 1963 , the first year of substantial longline fishing in the major sailfish grounds of the eastern Pacific Ocean, to 11 fish per 1,000 hooks in 1970; a decline of $86^{\circ} \mathrm{c}$

Similar declining trends of billfish catches were reported for other areas of the world by Dr. Ueyanagi in his review of the world commercial fisheries for billfishes presented during the opening day's session.

\section{Special Session: Mercury in Billfishes}

This special session began at 2000 on 10 August 1972, at the Hale Halewai in Kailua-Kona, Hawaii. Approximately 150 people attended; participants were mostly from the sport fishing fraternity. The purpose of the session was to provide participants in the HIBT and the interested public with the latest available information on the problem of mercury in fish and the opportunity to discuss the situation with experts on the subject. Presentations were made by the five panel members; two were summaries of scientific papers given at the International Billfish Symposium; two described work done in the State of Hawaii; and the fifth featured Dr. Kolbye, who described the effects of mercury on humans, the role of the FDA, and the rationale for its guideline level of $0.5 \mathrm{ppm}$ mercury in fish.

\section{Presentations}

\section{James S. Beckett \\ "Mercury in Northwest Atlantic Swordfish"}

Mr. Beckett reported that Canada banned the sale of swordfish in 1970. Up until that time the annual swordfish landings in Canada amounted to about 8 million pounds valued at $\$ 4$ million. Beginning in July 1971, a vessel of the Fisheries Research Board of Canada conducted longline fishing from Cape
Hatteras to the Grand Banks to obtain swordfish for analysis of mercury levels. During cruises in July and August 1971, 210 swordfish (lengths ranging from 74 to $247 \mathrm{~cm}$ fork length) were taken. Samples of dorsal muscle analyzed for total mercury showed an average of $1.15 \mathrm{ppm}$ and a range of 0.09-4.9 ppm. Differences in mercury level were noted between females and males as well as between tissues; liver and kidney had higher levels than brain tissue. Mr. Beckett reported that swordfish appeared to pick up mercury in southern areas and lose it during the summer on the feeding grounds in northern areas. His conclusion was that the source of mercury is volcanism in tropical areas and that mercury is being picked up by fish through the food chain. The full text of this paper is included in Part 2 of the Proceedings.

\section{Richard S. Shomura \\ "Mercury in Several Species of Billfish Taken Off Hawaii and Southern California”}

Mr. Shomura noted that since December 1970 , when the subject of relatively high mercury levels in tunas and swordfish became news, NMFS has had an ongoing sampling program to determine the mercury content in several important sport and commercial fish and invertebrate species. The 56 striped marlin taken from waters off southern California and Hawaii and analyzed for total mercury ranged in size from 56 to 231 pounds $(25.4$ to $104.8 \mathrm{~kg}$ ). The total mercury levels for white muscle tissue varied from 0.03 to 2.1 ppm; there was no obvious relationship with size of fish. Although the white muscle of 37 blue marlin also showed a wide variation, a trend of an increasing mercury level with increasing size of fish was noted. The mercury levels ranged from 0.19 to $7.86 \mathrm{ppm}$; fish size ranged from 96 to 906 pounds ( 43.6 to $411.0 \mathrm{~kg}$ ). Mr. Shomura reported that the total mercury levels in blue marlin livers ranged from $0.13 \mathrm{ppm}$ to a phenomenal high of $29.55 \mathrm{ppm}$. He stated that a comparative study of identical tissue samples analyzed by two laboratories showed wide variations in results; one lahoratory reported higher values consistently. He concluded by stating that the NMFS program was collecting mercury data as it relates to the fishery resources and was not presently addressing itself to the effects of mercury on mankind. The full text of this paper is included in Part 2 of the Proceedings.

\section{Cynthia D. Shultz \\ "Total and Organic Mercury in Marine Fish"}

Ms. Shultz reported that a part of their mercury study was concerned with determining the proportion of methylmercury in billfishes. A large number of marlin samples obtained with the assistance of NMFS were analyzed at the University of Hawaii laboratory and also analyzed by an expert in Sweden; the results of the two sets of analyses agreed very 
closely. Mercury levels in the billfishes ranged from 0.35 to $14 \mathrm{ppm}$. Of the total mercury, organic (methyl) mercury constituted a small percentage (up to $10 \%$ ). One example, a 155 -pound $(70.3-\mathrm{kg})$ fish, contained $4.1 \mathrm{ppm}$ total mercury and of this $0.54 \mathrm{ppm}$ was organic mercury. A regression analysis of all samples tested showed an asymptotic level of $1.55 \mathrm{ppm}$ organic mercury. Ms. Shultz noted that their studies indicated an upper level to the amount of organic mercury accumulated and theorized that any amount over and above this level was transformed into inorganic mercury and excreted. She also theorized that mercury in billfishes originates from natural contamination, possibly of a volcanic origin; however, much more work needs to be done in this area. This paper authored by J. B. Rivers, J. E. Pearson, and C. D. Shultz has been published in the Bulletin of Environmental Contamination and Toxicology 8(5):257266, 1972.

\author{
Albert C. Kolbye, Jr. \\ "Potential Health Hazards \\ of Mercury in Fish"
}

The full text of this presentation appears as Annex 8 of this volume.

\section{Richard E. Marland \\ "Status of Mercury Studies in Hawaii"}

The full text of this presentation appears as Annex 9 of this volume.

Discussion.-The following includes some of the more significant questions asked of the panel by the audience, and the panel's answers. ${ }^{5}$

George Parker (Kailua-Kona, Hawaii):

Ms. Shultz referred to fish tolerating a certain amount of methylmercury and then possibly converting it to another form of mercury which is excreted. Might this follow with humans?

Ms. Shultz:

We don't know the answer. Our data merely indicate that biotransformation may be taking place.

Captain Parker:

Does methylmercury keep being accumulated?

Dr. Kolbye:

The biological half-life of methylmercury is 70 days; to stay below the safe blood level the intake of methylmercury should not exceed 30 micrograms per day.

James Delohery (Australia):

Would you comment on selenium detoxification?

\footnotetext{
sFor purposes of brevity, the question and answer section has been abbreviated and in some cases paraphrased.
}

Mr. Beckett:

There was some work that suggested that selenium may reduce toxicity of mercury; however, more work is needed.

William F. Royce (NMFS, Wash., D.C.):

Why did FDA impose a prohibition on the sale of fish with mercury levels over $0.5 \mathrm{ppm}$ rather than merely warn the public such as is done with other products containing poison?

Dr. Kolbye:

The public has a varying understanding, a varying consumption rate and therefore FDA determined that a guideline was necessary in the interest of protecting the public. With respect to swordfish, $95 \%$ of the samples exceed the guideline. There are also FDA guidelines for other food items and toxicants.

Witek Klawe (IATTC, La Jolla, Calif.):

Would you comment on various articles criticizing the mercury guideline?

Dr. Kolbye:

FDA is prepared to defend the guideline.

Dudley C. Lewis (Honolulu):

Why were there no public hearings held before the guideline was set? Were any of the deliberations made public? Was the guideline politically motivated?

Dr. Kolbye:

Many guidelines do not require hearings. The guideline was reviewed extensively within FDA and by a panel of 12 experts. Testimony was given before the U.S. Senate. Scientific documentation was presented in the Journal of Environmental Health. I don't know if this is considered making it public. The question as to whether the guideline was politically motivated is ridiculous.

Richard F. MacMillan (Honolulu):

People have been eating marlin in Kona for generations with no ill effects. Therefore, I question Dr. Marland's statement that years and years of work is needed to come up with an answer. What is your reaction to the situation in Kona?

Dr. Marland:

There is no evidence of damage from eating marlin in the United States. However, there has been no systematic search for subclinical symptoms. Studies by trained medical doctors to look for subtle symptoms would be highly desirable; however, it cannot be done quickly or cheaply.

Richard H. Stroud (Sport Fishing Institute, Wash., D.C.):

Is the $0.5 \mathrm{ppm}$ guideline for total mercury? In view of recent findings regarding methylmercury not constituting $100^{\circ}$ of the mercury present, shouldn't the standard be for methylmercury? 


\section{Dr. Kolbye:}

The guideline is for total mercury. Methylmercury is the dangerous form, but much needs to be learned about the toxicity of all forms of mercury found in fish. It would be of interest to determine the exact chemical form of the nonmethylmercury part found in marlin.

Fred Rice (Kailua-Kona, Hawaii):

Regarding the University of Hawaii study-was mercury added to the feed of the swine? If the swine were fed marlin without the added mercury part, would there be any effects?

Dr. Marland:

Yes, mercury was added. No, they showed no effects if mercury wasn't added; however, controlled experiments are needed. It is not a question of just feeding marlin containing mercury without experimental controls.

\section{Mr. Rice:}

Is there any information available on what is being done with the marlin being caught? My guess is that probably $90 \%$ is being consumed by humans. Does the FDA have authority to intercede in cases where the fish is caught in Hawaiian waters and consumed in Hawaii?

\section{Dr. Marland:}

We don't know the disposition of the marlin caught. The guideline is a responsibility of the Director of Health for the State of Hawaii.

\section{Question:}

Has the economic impact of setting the guideline been considered?

\section{Dr. Kolbye:}

With the public health at stake it is necessary to act quickly. Severe cases in Japan showing diffuse brain damage give good cause for such a guideline.

Richard E. Young (University of Hawaii):

Would you comment on the case of the woman in New York who suffered mercury poisoning?

\section{Dr. Kolbye:}

Apparently this woman consumed swordfish daily; however, this cannot be fully documented.

\section{Captain Parker:}

Sweden made a mistake in calculating their guideline. Has anything been done to change it?

\section{Dr. Kolbye:}

They have not changed their guideline. Sweden has taken the following steps: (a) they close certain streams, (b) they advise that no more than one meal per week of fish from certain areas be eaten, and (c) they advise pregnant women not to eat certain fish.
Captain Parker:

How much trouble would it be to take samples of the dorsal muscle and determine the mercury level?

Mr. Beckett:

It would be extremely expensive-about $\$ 1,000$ per sample.

\section{Ms. Shultz:}

The amount of money is not the problem-time is-it requires $45 \mathrm{~h}$ to process each sample.

\section{Captain Parker:}

Is it true that broadbill swordfish landed in California are sampled for mercury and can be sold if found safe? What is the form of the FDA ban?

\section{Dr. Kolbye:}

Regarding swordfish in California, as far as I know, they are being handled as you have noted. The tuna and other industry people are cooperating in conducting such monitoring programs. It may be possible to do this for marlin; however, it must be done by an accepted laboratory to assure that it is done correctly.

\section{Captain Parker:}

What did the general public hear with respect to marlin in Hawaii? Are we breaking the law if we give away fish?

\section{Dr. Marland:}

The Director of Health in Hawaii publicized the fact that the marlin contain unsafe levels of mercury, and received a voluntary withdrawal of billfish from the market. If fish are given away it breaks the gentlemen's agreement. If the fish are not fit for human consumption, they should not be given away or eaten under any circumstances.

Peter S. Fithian (Honolulu):

Throwing away fish is a philosophical problem. We have run out of time. Thank you all for attending and contributing to this most worthwhile discussion.

\section{Special Session: Sportsmen-Scientists}

\section{Symposium Summary (Frank J. Hester,} USA).-Dr. Hester provided the sportsmen-scientist gathering with a summary of the results presented at the scientific sessions and the special session covering mercury in billfishes. His presentation was made with the aid of a number of slides which were used by the various speakers. Since Sections 5 and 6 include summaries of the sessions, and the full text of the papers is given in Part 2, only Dr. Hester's closing statement will be included here. It follows:

I would like to make some general comments. Billfishes, because of their size and scarcity, are very difficult animals with which to work. It is very difficult to find fresh material and even more difficult to find living material. These are probably the main reasons why today the state of knowledge of billfish 
biology is really not very far advanced. We are certainly always very grateful for the opportunity to take advantage of a tournament like this, where one can actually see the fish when only a few hours old. This, along with the logbook recording, the cooperative tagging programs, and the information from the commercial fisheries probably is going to mean that in the next decade we will begin to understand these animals much better. To bring about this understanding will require considerable work on the part of the angler, who will have to be prepared to keep detailed records, and either mail them in or have them delivered at dockside. You will also have to put up with the occasional biologist "poking around" your fish. Finally, you should be prepared to change to the metric system of measurements in the very near future and this means you will have to rewrite the International Game Fish Association (IGFA) world records. Thank you very much.

Panel Presentation (R. S. Shomura, Symposium Cochairman). - I would like to start by stating that we are extremely fortunate-and I think this was excellent planning on our part-in having as Chairman of this morning's Sportsmen-Scientists Panel Session Mr. Dudley Lewis, who took the winning prize in this year's HIBT tournament. It is also fitting that he assumed the post as Session Chairman at this closing meeting, since he is the only sportsman-angler who has participated in all 14 of the HIBT tournaments. Mr. Lewis was born in Hawaii some few years ago and has been fishing all of his life. He is presently a practicing lawyer. It gives me great pleasure to introduce Mr. Dudley Lewis.

\section{Lewis (Chairman)}

Ladies and gentlemen, the format of the Symposium this morning is the following. We have with us three sportsmen and three scientists and I will call alternately on each of the scientists and sportsmen to make a short statement. At the conclusion of their remarks we will welcome questions either from the panel or from the audience. First, I will call on Dr. C. Richard Robins, University of Miami Professor, who has done a lot of research on billfishes, to give you some idea of his work and what can be done to further the dialogue between scientists and sportsmen.

\section{R. Robins}

I want to start not with an account of what I or my colleagues have done at the University of Miami, but with some of the problems that we run into in dealing with billfishes and what we need in the way of information.

Firstly, we have lost much valuable data from the photographic record that would have otherwise been available to us. If one goes to any of these tour- naments, one cannot help but be impressed with the number and quality of the cameras but, from our standpoint, many of the photographs are of poor quality. Of course, we have nothing against the types of photographs that you want for your own records, but Don de Sylva and I very frequently are called upon to identify fish from photographs. It is extremely difficult to do so when the fish is hanging up and the cameraman is very close causing foreshortening, which jeopardizes our obtaining good body proportions. Very often the angler, the captain, or mate will have his hand over some very critical character such as the dorsal or pectoral fin. In taking photographs this is really what we need. First of all 1 think that every photograph should have a small identification tag with it-it can be just a piece of paper like we've had at this tournament-which indicates the locality of capture of the fish, the weight, and the length. Photographs have a habit of going astray for many years and then we get a whole pack from a person saying, "I think this is a fish I caught off Malindi, Kenya," when in fact it may have been one that was caught at Bay of Islands, New Zealand. This leads to difficulties, so if you have an identification tag as part of the photograph there is never any question about the origin of the fish. The next thing is to try to take the side view of the fish with as little distortion as possible. It is often very easy to get to the tower on your boat and shoot a picture of the fish in the cockpit with very little distortion. In other cases it is very simple to allow the fish to hang, as you often do here at Kona, then back off and take a telephoto shot of it and this reduces the distortion.

In addition to the side view, it would be very helpful to take a picture of the underside of the fish, at least from the area of the anus forward. The position of the anus relative to the anal fin is very different in the different kinds of marlins, especially in the Atlantic Ocean. In the spearfish the anus is very far forward, in the white marlin it is very far back, and in this new species we call georgei it is in a sort of in-between position.

This undershot can also show the very important shape of the pectoral fin. Marlins are wonderful machines, being really well adapted for high-speed swimming in the ocean. The blue marlin, as you know, maintains its depth a long way aft, so if you take the center of gravity of this fish, it is fairly far back. These animals can swim along very efficiently and they keep their pectoral fins pretty much back toward the socket. The black marlin has its weight far forward and really is front heavy. If you could cut the pectoral fins off this fish, it would pitch and go right down toward the bottom. Its pectoral fins are therefore actually stabilizers. If you look at the cross section of the pectoral fin of a black marlin it is very different from that of a blue marlin, being shaped like the cross section of an airplane wing. This fish really flies through the water and gets lift to compensate for pitch. The pectoral fin alone can distinguish the blue 
marlin from the black marlin, and yet in many photographs Don de Sylva and I are unable to tell anything about the pectoral fin because the fish is hanging up and the fin very commonly will flop down. The shape of the dorsal fin is also important.

I think it really doesn't cost very much to take three photographs, one of the whole fish, one from underneath, and one close-up view of either dorsal fin or the pectoral fin. But don't forget the identification plate with the geographic information on it as a permanent record.

I would like to direct this next remark mainly to the scientists. If you ask anglers to do something, then you should give them specific instructions as to what it is you want, and when you do this you assume certain responsibilities. Nothing makes me madder with scientists than to have one of my colleagues commit anglers to doing something and then never follow-up on it. I've seen the late Al Pfleuger of Miami spend a lot of money, and an awful lot of time, gathering data for some biologist and after he did all of this nobody would show up. I think this is the kiss of death in cooperation. If you ask anglers to do something, you have an ethical responsibility to pick up the information and to provide them with some sort of a report on what it is that you have done with it.

\section{Lewis}

Thank you very much, Dick. I will call next on Peter Goadby, an outstanding sport fisherman and author who has traveled all over the world.

\section{Peter Goadby (Australia)}

Australia's offshore game fishermen have always been proud of the fact that they have cooperated actively with scientists. Being somewhat isolated, we have realized that the sport fisherman is in a unique position to help the scientist because they are the only ones that can help us with things we are unable to learn. If we record data accurately then the scientist can give us a lot of help. We are as proud of our contribution to the "establishment" with the capture of blue marlin at Cairns last season as with the 10 marlin we caught averaging 1,000 pounds each. We are fortunate in Australia at the moment that in addition to the various government agencies and institutions, there is a well-founded university coming into being at Townsville just 250 miles from the Cairns marlin grounds. There is every indication that some research on the black marlin will be undertaken at this institution.

The cooperative tagging program in Australia has had remarkable growth, and as an Australian fisherman I take my hat off to NMFS for the assistance they have given us. It gave us pleasure slamming a tag into a fish knowing that the tag had come from the United States and that the information would come back perhaps from a Japanese or Taiwanese longliner through the United States. This really made us feel we were part of a worldwide program. The growth of tagging in Australia is interesting as $10 \mathrm{yr}$ ago there were probably no more than two or three fish released in any one season and recoveries were nil. As you have already heard, there have been two black marlin recoveries already. The first fish was out approximately 360 days and was returned only 100 miles from where it had been tagged. The second one, 1 of the 169 fish tagged at Cairns last season, was out only 110 days but had traveled something like 1,440 miles in that time. Tagging is now being started in New South Wales and later we will have the help of anglers even farther south. The program will be not only on marlin, as we are encouraging anglers to tag and release every kind of fish including offshore species of sharks like hammerheads, makos, and blue sharks. We are not really encouraging the release of white or tiger sharks, because we feel if someone got "chopped up" on the beach and a tagged shark was caught we would certainly be in trouble.

Anglers in Australia have long shown their interest in cooperating in any overseas programs. We were most happy to cut the pectoral girdles from black marlin to send to Dr. Robins, and to provide data on the blue marlin in the Pacific. We would be most happy to give any help we can on the size and movement of the black marlin, or anything else anyone wants to do on that species. The same applies to any studies on sharks. We still have a lot of dangerous species of sharks in Australia, and if anyone is interested in them we would be happy to help. As I said previously, this meeting of fishermen and scientists is really great, and I believe the best thing that has happened in sport fishing probably in the last $100 \mathrm{yr}$. We have always known the names of a lot of scientists, and I guess similarly the scientists have always known the names of a lot of interested charter captains and interested sport fishermen. Now we have got names to go with the faces and faces to go with the names, so let us all keep in contact and go forward from here on.

\section{Lewis}

Thank you very much, Peter. I shall call on Mr. William Craig, formerly with the California Department of Fish and Game and now with NMFS.

\section{W. Craig (USA)}

I obtained my experience with the billfishes, primarily striped marlin and broadbill swordfish, during my time with the California Department of Fish and Game. My main responsibilities were to other major programs and moving around in the billfish fishery was quite incidental and confined simply to compilation of adequate catch statistics for these two species. The mercury problem last year finally gave 
me an opportunity to join the "blood-and-guts" detail and to see what a striped marlin looks like. I had, of course, every cooperation from the local sport fishing clubs in California, as otherwise it would have been a monumental task to try to gather all these specimens of striped marlin for determination of mercury content. I might go back and say it was a mandate from the big-game sport fishermen in southern California that made the Department undertake a program to try and clarify the situation with regard to mercury. We collected striped marlin samples and delivered the results of the mercury analyses to the sport fishing clubs. Cooperation can be obtained from sport fishing clubs by working with them but reiterating what Dick Robins said, do not ask for something unless you can follow up on it.

Additionally, I would like also to indicate the value of club yearbooks. Some clubs just report their annual catches and their annual buttons and awards, while others present historical data on catches and incidents that took place. One particular club yearbook contains a couple of articles by lawyer members that contribute much to our knowledge. I wish to call these types of publications to the attention of scientists because there is certainly a great deal of merit in what the sport fisherman has to offer from his on-the-spot observations. I brought these particular two yearbook issues for Dr. Ueyanagi, because they contain some data on the marlin weight-frequency distributions in the southern California fishery. These data were collected since the publication of his joint paper with Colonel Howard. My small mercury program last summer, which was just a "news note," was picked up and published in this little booklet. If club articles warrant it, and are called to our attention, perhaps we can see that they obtain wider distribution than the clubs themselves can provide.

\section{Lewis}

Thank you very much, Bill. I next call on Mr. Richard Stroud, the Executive Vice-President of the Sport Fishing Institute, who will make some remarks on the role of that organization.

\section{R. Stroud (USA)}

It's a great pleasure to be here, first because it's the first time I have ever been to Hawaii and secondly, because I guess I am unique at this gathering since I am the only official "hybrid" to appear before you. Although I am sitting on the sportsmen side it is hard for me to determine whether I am really a sportsman or scientist-perhaps a little of both. I have worked in both areas and I enjoy and participate in sport fishing to a great degree. Nevertheless I would like to take a little time to acquaint you with my organization. On the table I have put some propaganda which explains the nature and purpose of our organization and also some application blanks. I have also prepared a few mimeographed comments on the role the Institute has played over a long period of time and I invite you to take a copy later.

The Sport Fishing Institute is the only national nonprofit, tax-exempt conservation organization devoted wholly to the conservation of fisheries resources, and it was designed to help fishing and, consequently, fishermen. It was established in 1949 and functions as a research, education, and professional service type Institute, and is staffed entirely by fisheries scientists. It was designed to be a catalyst for development and promotion of the application of all types of progressive fish conservation programs in order to enhance the sport of fishing.

In the course of general overviews of fish conservation it became very apparent, a couple of decades ago, that very little was being done in the inshore area between the seashore and the high seas. The existing institutional agencies were concerned either with inland types of resources or high-seas resources. There was real diversion of interest away from the very critical and sensitive area of the coastal zone and estuarine areas which are vitally important to the continued survival of many of our game fishes. Consequently, we attempted to stimulate a lot of activity in this area and founded a research program of our own, small in size but designed to stimulate interest. I think we were successful in doing that. We began making grants as early as 1952. Our first research grant in the billfish area was a small one made in 1958 to an investigator at Yale University to work at an east coast tournament similar to this one. We made a follow-up grant later to South Carolina University in 1959 to develop further studies on the life history of the blue marlin and white marlin. Then we became interested in the work that Frank Mather was doing at Woods Hole, the Cooperative Game Fish Tagging Program, and for more than a decade have provided small but continuing annual support to that program.

Based on the research we have done, and the obvious problems and needs that existed, we felt it was necessary to enlist the support of the Federal and State governments as much as possible. We have great interest in the Dingell-Johnson Program, which is supported by an excise tax you pay when you buy a reel or big rod. These funds are channeled to the States, which were stimulated to use some of this money for marine game fish research, but there was nothing being done at the Federal Government level. The then Bureau of Commercial Fisheries was interested almost exclusively in the high seas. So we drafted a bill, which eventually became known as the Marine Game Fish Research Act and this was passed in 1959. This marked the formal entry of the Federal Government into this area of concern which had been previously neglected.

Early in the 1960's, as you are all well aware, Japanese longlining exerted fishing pressure on the stocks with an evident adverse impact on sport 
fishing. I am not going to go into that as the analyzed data and results are well known. In any event it was decided to hold a meeting in Rio de Janeiro in 1966 to consider the formation of a conservation organization to be concerned with research and management of the tunas and tuna-like fishes of the Atlantic Ocean. I was fortunate enough to be an advisory member of the U.S. delegation, together with a representative of the Bureau of Sport Fisheries and Wildlife (the late Albert Swartz).

Preceding the Rio conference, a series of meetings was held with representatives of sport fishing interests nationwide, at which we tried to determine the course of action we might possibly pursue in Rio. We decided there were several things we ought to do. First, and most important, we sought to have a separate meeting with representatives of the Japanese delegation, particularly the private individuals representing the commercial fishing industry. We sought four objectives: 1) recognition that there was a significant problem of mutual concern due to the longlining activity; 2) agreement that the longliners should remain a sufficient distance from billfish sport fishing centers to preclude direct conflict; 3) an agreement that eventually there would be convened an international scientific conference on billfish biology; and 4) management following not less than a decade for research.

The Rio conference resulted in the establishment of the International Commission for the Conservation of Atlantic Tunas and this also embraced responsibility for research and management of billfishes. The conference also provided the hoped-for opportunity to talk with Japanese commercial fisheries interests. As a result the objectives that I have outlined were substantially agreed to and, in return, the U.S. sport fisheries representatives agreed to promote cessation of destruction of Japanese longline gear.

Following the conference, we came back here and held a series of meetings across the United States with representatives of sport fishing groups promoting this latter part of the agreement. Obviously, if you are going to get something you have to give something in return and it seemed to us that this was a very reasonable arrangement. Until recently, aside from a few temporary minor relapses, matters seem to have worked out well since conclusion of the agreement at Rio. Several incidents have occurred, though, which underscore the usefulness of the agreement. In the spring of 1967 for example, my organization formally requested that the Japanese overseas trawlers association revise previously announced plans for exploratory trawling along the east coast of the United States. As a result of several exchanges of correspondence, these plans were substantially altered so as to operate in waters north of the Miami-West Palm Beach area in Florida, and offshore, well beyond the range of the 1day charter trips out of the more important angling ports along the Atlantic Coast from Florida to East- port, Maine. Last year several Japanese longliners commenced fishing in the Gulf of Mexico, and are continuing to do so this year, and have come into conflict with the long range, private charter sport fishing craft characteristic of that area. There was a flurry of excitement over an alleged mass harvest of billfishes based on shark fins, hung to dry in the superstructure of a Japanese ship being misidentified as marlin tails. I had it on the best of authority from NMFS people that these were indeed shark fins. This point was cleared up, but the longliners remained sufficiently close inshore to come into occasional contact. I understand that some of them have drifted even beyond the legal limit in the past few days, perhaps accidentally. Based on documented data provided by the Coast Guard on request, and also through the help of NMFS, we relayed this information to our Japanese contacts and suggested that they have a special problem in the Gulf of Mexico. We urged that they instruct their fishermen, if they intended to continue implementing our unofficial agreement, to move farther back offshore. As yet, nothing has been done but we have some information which suggests such instructions will be forthcoming.

It seems to me that it is highly desirable that "environmentally concerned" sport fishermen refrain from the destruction of Japanese longline gear. I cannot emphasize too strongly that if there is to be any kind of a quick settlement to the benefit of American sport fishermen, then we have to hold up our end of the bargain. If it turns out that the Japanese have decided to abrogate the agreement, then we will have to see what other measures may be taken. I am not convinced yet that the agreement is without viability at this time and I believe that we should do everything we can to show we are holding up our end of the bargain.

I want to put in a special plea in terms of the official role I am supposed to fill here. As far as sportsmen are concerned, I think one of the things you must do, if we are going to find out enough about billfishes to eventually hold out hope for a bilateral treaty conference with the Japanese and to work out an international rational management plan for these fishes, is to provide money for this research. I do not necessarily mean directly, but at least indirectly, through support of appropriations to the agencies who are doing work. Obviously this is very expensive research, and you have had examples of it here. For example, if we are going to build saltwater study lakes to support adult black marlin as we have heard suggested, I can see that it is going to be fantastically expensive! Even when we are talking about $\$ 120$ tags, that also is pretty expensive. I think there is going to be a great effort made on the part of the Federal Government (NMFS) to show they are spending an awful lot of money right now on billfish research. They are going to take all the different pieces from existing programs with commercial fisheries activities and say "this is what we are 
doing and we are doing a good job." But what we want is additional research if we are going to have answers to these problems. We have got to have additional money to do it and that has got to come out of appropriations made by the Congress.

I can tell you right now that the Congress is not very sympathetic and this means you are going to have to get some political pull behind this thing. You are going to have to write your congressmen and tell them to give these boys (NMFS) the money. Our organization will try to spread the word when appropriations time comes around. From the standpoint of the scientists, obviously, I think we want them to do the work and provide the information that's necessary to come up with the rational management programs. However, I think I would suggest at this time that, philosophically, the scientists are going to have a very difficult problem. They have based most of their work in the past on the concept of maximum sustainable yield, having been trained this way, as this has been the cornerstone of commercial fisheries management. I submit to them that this has been an inadequate philosophy for rational management of sport fisheries.

\section{Lewis}

Thank you very much, Dick. I now call on Mr. James Squire, who is a fishery research biologist with NMFS in La Jolla, Calif.

\section{James Squire (USA)}

I am with NMFS in La Jolla though formerly I was at the Tiburon Laboratory. You heard Dick Stroud state that about 1960 the Marine Game Fish Program was established and one of the laboratories that it had started was at Tiburon, Calif., with which I became associated in 1960. This laboratory was exclusively for marine game fish and this function shifted to NMFS in 1970 , when there was a revision of programs. I moved down to La Jolla with a program to study billfish migrations through the tagging programs in the Pacific Ocean area.

There is concern for the billfishes in view of a new increase in the utilization of these resources as indicated by actual decline in the worldwide catch of billfishes. As Dick Stroud pointed out, if you are to attempt to manage this resource you must certainly take into account the needs of the users, both sport fishing and commercial. We manage these things in different ways, the commercial fishery on maximum sustainable yield and the sport fishery on large numbers of big fish. These two concepts are in conflict and will certainly have to be resolved in the future.

In 1961 we became involved in billfish research in the eastern Pacific Ocean, primarily life history work and the tagging program, looking forward to the day when such information will be needed to make rational management decisions. We indicated at this meeting the problem of obtaining good catch and ef- fort data and this is a field where a sportsman can contribute greatly to research. We get good catch and effort data from the Japanese commercial longline fisheries throughout the world but the collection of similar data from sport fisheries is very poor. What is needed is better fishing logs, and people must be willing to carry them and fill them out to the best of their ability.

The purpose of all this catch and effort data is to show effectively the catch rate in the sport fishery and how this is possibly being affected by changes in the catch rates in the offshore commercial fisheries, which sample a greater number of fish throughout the eastern Pacific Ocean. I think we can say that the sport fishery probably takes about one twenty-sixth the amount of fish that the commercial fishery takes in the eastern Pacific Ocean. Despite these good data from the commercial fishery, one needs to know how it is affecting the sport fishery if one is involved in any international negotiations. You have to have the scientific proof. This is the reason for encouraging sportsmen and clubs to keep better records of catch and effort. Not only are we interested in the days of fishing with catches, but we are interested also in the number of days when people go out and do not catch fish. Using only days of effort which produce catches does not give a true measure of what is actually going on.

We certainly need more data on environmental factors such as temperature and water color. As F. Williams said here yesterday we are studying a living animal in a moving environment and everything is changing from day to day. We need to know how billfish move in relation to the environment because this may tell you why you are not catching fish. There are possibly two reasons, either the environment is not right for the fish, or the year class strength is low and there are not many fish around. To determine which of these factors is more important we must know something about both.

We need to know more about migration patterns which sportsmen have assisted us with in the past and are continuing to do. We must define the normal range of the fish in the ocean, as this has a very definite influence on the type of management you might use for the resource. For instance, in the albacore fishery of the North Pacific Ocean you can take fish off Catalina, Calif., and then some 5 mo later they will be south of Tokyo, Japan. You certainly cannot just manage the fish off California, as the resource is ocean wide. This is why migration studies are important. Another example would be the yellowfin tuna in the eastern Pacific Ocean. Scientists have tagged many thousands of them and found a north-south migration pattern with very little east or west movement, so they drew a boundary line at long. $130^{\circ} \mathrm{W}$. Does this hold for billfish or are they transpacific migrators? This is one of the reasons for starting the tagging program. 
I think sportsmen realize we have a high mortality rate with tagged billfishes, but they are still willing to tag these fish. I see a challenge here to the sportsmen to find better ways of hooking fish or getting them alongside so that they can be more easily tagged, thereby reducing mortality from this cause. At present the only way to catch billfish is by hook and line either with the longline or rod and reel. An exception is by harpooning them and that is not very satisfactory for our purposes.

We need to know the economic value of sport fisheries. The billfish catch by sportsmen is not great, but the sportsmen spend a lot to catch them.

The sportsmen, as Dick Robins said, assist us in the collection of biological data but there is one thing that I think they could collect in addition to weight, and that is length; of course, some do this routinely. We should also collect data on the sex of the fish and this is not so difficult. In summary, we should give a little training and urge the marine game fishermen to take an interest in the billfish resources and the future management of them. As Dick Stroud pointed out this needs funds not only from our country but from other countries around the Pacific Ocean (and worldwide). These countries or states should be encouraged to conduct additional work on the billfish resources off their coasts. I urge the marine game fishing world as a whole to get a copy of the Proceedings of this meeting and to read it, because I think you will find we have summarized just about all the knowledge on billfishes worldwide. Hopefully this will give us a better informed and enlightened marine game fisherman geared for the billfishes.

\section{Lewis}

Thank you very much, Jim. Our last panelist is one that I am sure you all know. You have certainly heard about him, he is one of the pioneer charter captains of Kona, he's been at it a long time, he is knowledgeable, and it gives me great pleasure to present another good friend of mine, George Parker.

\section{G. Parker}

Thank you, Dudley. I am a charter boat skipper and I think I have been at this for 28 yr now. This year I am president of the Kona Charter Skippers Association which comprises some 18 , possibly 17 boats now that we lost a boat last night in the Kona area. I have just thought of a real good reason for all of us being here, in addition to the reasons that are quite obvious. It is said that this globe is covered three-fourths by water and only one-fourth by land, and it is for sure the good Lord intended for us to spend three-fourths of our time fishing and the balance ploughing.

I cannot tell you how excited I am about this meeting. Kona is just bursting its seams with scientists and other people knowledgeable about billfish; all kinds of fish for that matter. I want to emphasize that Kona is certainly proud to have you all here from all over the world for what I understand is the first ever Billfish Symposium. The Charter Boat Association, which I represent here this morning, could not be happier about this event.

It has been said that it is important that the charter boat captains and crews, as well as the private sport fishermen, realize that they can be a very great help to the scientist. They should be alert and report the things they see, the things that happen aboard the boat relating to fish, water currents, temperature, and other conditions of interest. For example such facts that one day we see thousands of porpoises then the next day there isn't a porpoise near the boat. Or when the humpback whale comes down here what happens then? Does he scare off all the marlin? Do the currents make that much difference to our fishing? We all encounter these things when we're at sea but we don't record them, and although we talk over the Citizen Band (CB) radio to each other about what we think the current is doing and why we are, or are not, catching fish, it never seems to get beyond our association and our daily conversations.

Possibly one result of this meeting and what's been said here this morning might bring about a form that we could have aboard each charter boat to be filled out. We have plenty of time between strikes and it doesn't have to be something to be done after you get home when you're so tired and can't think straight. We all have writing space aboard our boats. We could have a pad of forms to fill in, even if it's virtually reduced to a form where you just check off the items as you go down a list. At least we have to do something more than we're doing at present. We've got to help the scientists with our firsthand knowledge. We're out there on the grounds rather like a weather ship out on the channel that reports the weather as it comes through, so we are the outposts and we have to respond about fishing. At the coming meeting of the Charter Skippers Association we are going to have some time devoted to the form of help we can offer to the scientists and in turn to ourselves. The realization of what we can do has been growing. Even before this Symposium some of our skippers have been recording certain types of information. It even occurred to me to put a tape recorder aboard my boat and tape what comes in over the CB. This could be one way of starting a record of daily fishing conversations; possibly some one on the shore, who has a good $\mathrm{CB}$ radio could tape record some of the fishing conversations that go on off the Kona coast.

We are so fortunate here to have a calm, comfortable sea to fish in and some days with a lot of fish. I wonder if we realize how lucky we are. Most good billfishing areas are so rough that you are standing on your beam ends and yet people still go out fishing for them. I would say we are spoiled here with our lee shore that extends out so far that $95 \%$ of the time we hardly have a whitecap. I think the 5 fishing days of 
this tournament have shown people what the Kona coast can be like and why it's so easy to enjoy a day at sea and land a billfish, if you're lucky enough to hook into one.

Lately we have heard a lot of discussion on conservation of fish and possibly the mercury in billfish scare has emphasized this. The belief is now that there is a dangerous level of mercury in the blue marlin and here in Kona we catch more blue marlin than anything else. As I have said before, and I will say again, part of the revenue in the charter service is the sale of fish, if and when the angler leaves it with the skipper. We depend on that sale and it has been some help in holding down our charter prices and without it we are seriously hurt. The blue marlin revenue is shared between the skipper and the crew and some of the boats have gone out of service because they could not take that decrease in the share of the profit. However, it is an ill wind that does not blow some good, and here the good is concerned with conservation of billfish.

I think it's a general trend at Kona that if a person catches a billfish and it is his first fish, we usually keep the fish because the ego has to be built up with a photograph of the fish hanging at the dock. We can well understand that and it is worthwhile, as well as a beautiful advertisement for the Hawaii tourist industry. So we take that first fish, but how about the second and subsequent fish? The skipper and crew ask the angler if it is just another fish as far as he is concerned or does he care to have the fish mounted. This may be a little expensive for him so they ask if he would like to release the fish and let him fight again. The angler often agrees. Of course there is always the person who can afford to have the fish mounted, so the fish is landed.

The next question relates to the type of tag we can put into the fish and how it can be found later. A tag, such as a small dart, can be put in the dorsal muscle of the fish and the time between the first and second capture will show the distance traveled, growth, and possibly conditions under which he is caught. I think we are all fairly familiar with the dart tag procedure, but the previous speaker, Mr. Squire, alluded to something which made me feel I should talk about a type of lure that is able to bring the fish to the boat without injury. Without any blood being shed, and without any interference with his swimming or breathing, the fish can be brought to the boat and kept almost stationary though you have to act quickly if you're going to tag and release the fish. A lure was developed here in Hawaii about 3 yr ago, and has been improved since then. The concept of taking a billfish with this lure is just the reverse of a normal lure in that this lure has no hooks at all. This new lure was developed with the idea that the billfish already provides the hooks on his bill. The bill in each billfish is covered with a lot of fine teeth and when proper material is applied to that bill you can hold him with the bill and bring him to the boat. As a matter of fact you hold him so well and can guide him to the boat much easier than if he is hooked in the mouth. You can use much lighter tackle to do it. I think that's what we're after.

I understand from a discussion last night with one knowledgeable person that probably it is not the hook or the dart tag which kills the fish or shortens his lifespan, but an accumulation of lactic acid from use of oxygen during the fight. I understand that oxygen is stored in the red muscle of the fish for an emergency. Then during the fight on rod and reel if he uses it all he is at the same point as the boxer when he is hanging on the ropes. Possibly this is what we have to avoid when we tag a fish, that is, we have to eliminate the fight on rod and reel. We go out purposely to tag a fish, possibly with a sonic transmitter in it, and then perhaps the fish will live no longer than $48 \mathrm{~h}$. I believe when the last taggings were done here with sonic transmitter, the billfish did not survive long enough to get the information that was really wanted. We had a special boat down here with all the sonic gear and it seems a shame that these fish appeared to die so soon. I suggest that the new type of lure with a transmitter could be used to tag the fish without a fight; the leader would break after the fish had taken the lure and then the chase with the listening devices would go into effect.

Again I want to welcome you all to Kona on behalf of all the skippers, even those who aren't here this morning. I know they think sport fishing has developed to a very fine point, when these scientists will spend their time and their energy to come and hold a symposium on billfish. I think sometimes we underestimate the importance of the billfish here in Kona, and it was not until the international billfish tournament, originated by Peter Fithian, that we really started to make some strides and realize the importance of the billfish fishery. I take my hat off to Peter Fithian who has brought this to fruition.

\section{Lewis}

Thank you very much, George. The meeting is now open to questions from the floor. ${ }^{6}$ Please identify yourself as this session is being recorded.

\section{Discussion}

Mr. Lewis:

In my privileged position as Chairman, I would like

\footnotetext{
${ }^{6}$ For purposes of brevity, the question and answer section has been abbreviated and in some instances paraphrased. Also, questions relating to the mercury problem were similar to those raised during the special session on mercury; thus these have been omitted.
} 
to ask the first question. Why do scientists have different length criteria for billfishes??

\section{Dr. Robins:}

Generally billfishes from commercial catches or those found in the market places around the world have their bills cut off. If you are dependent upon a measurement that includes the bill then a great deal is lost unless adjustment factors can be used to determine a given length. Also, the bills in two groups of billfishes grow differently.

\section{Captain George Parker (Kona) (comment):}

For a long time there has been some confusion on what constituted a black marlin and how it differed from a blue or striped marlin. In a black marlin the fin is stiff from the outset and you cannot lay it back to the body without breaking the joint; this is not true of the other species.

\section{Mr. Goadby (Australia) (comment):}

The pectoral fin of small (less than 100 pounds) east Australian black marlin can be moved, though they will not lie back completely flat as do those of the blue and striped marlins. Therefore, we must use other identifying characteristics.

\section{Mr. Palmer (Australia):}

During a day's fishing a fisherman is likely to see a varying number of fish, sometimes surfacing, and sometimes encountering a strike then a miss. To what extent must the data be collected to be useful to the scientist?

\section{Mr. Squire:}

The amount of useful data collected depends on the circumstances and the fishery. We have obtained good data on catch per angler day by use of the card mail-in system. In some fisheries more detailed data are collected by the logbook method. What is needed is a standardized log which will ensure receipt of the kind of statistics needed for the sport fishery.

\section{Dr. J. Delohery (Australia):}

A question to Mr. Stroud. The Atlantic Ocean tuna agreement includes billfishes, while the Indo-Pacific and Pacific Ocean agreements do not. How can we get billfishes included into those two agreements?

\section{Mr. Stroud: \\ You would have to amend the articles of the Convention. In case of the ICCAT, the term "and tuna-like fishes" was included and defined so as to specifically include the billfishes.}

\footnotetext{
'During the course of the Symposium sportsmen and scientists commented on the need for a standardized set of measurements for hillfishes. There was a consensus agreement that the publication by L. Rivas entitled "Definitions and methods of measuring and counting in the billfishes (Istiophoridae, Xiphiidae)" should be reproduced in this volume, since it is currently out of print. Rivas' paper appears as Annex 10.
}

Mr. Shomura:

A clarification of a point raised by Mr. Delohery. I believe the Indo-Pacific agreement quoted by him relates to the Indo-Pacific Fisheries Council. This is only an advisory body and I believe does not currently have any management responsibilities.

Mr. Lester Walls (Oahu):

I would like to know if the silver marlin is a definite species or a juvenile fish.

\section{Dr. Robins:}

As far as we know in the Pacific Ocean we have a black marlin, a blue marlin, a striped marlin, a sailfish, and a shortbill spearfish. We have no evidence that there is any other kind of marlin-like fish in the Pacific Ocean. The fact that this "roundscale" spearfish or "hatchet" marlin has been uncovered in the Atlantic Ocean indicates that an eye needs to be kept open for things like this.

\section{Mr. Frank Moss (Sport Fishing Annual):}

Most fishing tournaments generally follow the IGFA rules. These rules are predicated on the use of hooks, so the question arises about IGFA acceptance of a hookless lure.

Mr. Elwood Harry (IGFA, Ft. Lauderdale, Fla.):

The IGFA through its international committee and clubs has overwhelmingly voted down the use of any entangling devices.

Mr. Frank Mather (USA):

Question to Peter Goadby. Is a billfish which "lights up" more apt to strike than one that does not?

Mr. Goadby (Australia):

It appears that fish "light up" more in warm water than they do in cool water. One angler reported that of 11 marlin he caught that had followed the bait, only 1 was seen to "light up." On the other hand in Cairns, black marlin are observed "lit up" from the time they are first sighted. It is my personal belief that the phenomenon is like birds exhibiting their brightest plumage during the mating season.

Mr. Eugene Nakamura (USA):

I would like to direct a question to some of the sports fishermen here. Fishermen in the Gulf of Mexico do not use artificial lures when fishing for billfish, but use fresh or frozen fish. Yet in this area (Hawaii) just about all lures are artificial. Why?

\section{Captain Parker (USA):}

This question comes up frequently on the charter boats. If we need live bait we catch them on the fishing grounds. Anglers are surprised that we troll for so long with artificial lures. We troll at high speeds in order to cover the maximum area. At these speeds it is difficult to maintain a frozen fish or even a freshly caught fish on the hook for any length of time. Also, we consider that the sound of the propeller and the boat's wake, the sound that the lure makes "diving" 
in the water, and the trail of air bubbles created by the lure, are all very important factors. In our experience, the artificial lure also has taken more of the large fish than the skipping bait or the live bait. Each area seems to have one favorite fishing method which is considered to catch the most fish.

Mr. R. Johnson (Sports Illustrated):

Question to Dr. Robins. Does the hookless lure extend the life of the fish after it has been released? This is apart from any questions of tournament rules.

\section{Dr. Robins (USA):}

I am not familiar with this particular lure. I am personally convinced that the reason a lot of fish, particularly blue and black marlins, die after release is the build up of lactic acid in the body after they have been "played" for a long time. To investigate this problem we need to use sonic lures and track the fish after release.

Mr. R. Johnson:

Does Captain Parker consider it possible to maintain a charter business with customers going out with the understanding that they are to use a hookless lure?

\section{Captain Parker:}

Yes. Trying to build a lure that will hold the fish on the end of the line has been the desire of man ever since fishing began. May I remind you of the advent of nylon lines, the glass fiber rod, and the two-hook lure.

Mr. Lewis:

As there appear to be no further questions, I will ask Peter Fithian to summarize this session.

Mr. Fithian:

Thank you, Mr. Chairman. Dr. Robins talked about the valuable information that could be derived from good photographs and how these should be taken to avoid distortion. An identification tag showing location and time of capture, and weight and length should be visible in the photograph. He said that scientists must follow up on what they request from the sport fishermen and I agree that this is a very important point.

Mr. Goadby spoke of the active manner in which Australian oceanic game fishermen have cooperated with marine scientists, especially in tagging programs. Results from these have already suggested some interesting migration patterns for the black marlin off the east coast of Australia.

Mr. Craig commented on the value of records and other data in fishing club files and how useful club yearbooks can be to the scientist. I know that Mr. Harry of the IGFA always asks clubs to send in their yearbooks and it occurs to me that this might be the simplest way for scientists to get hold of them.

Mr. Stroud spoke about the activities of the Sport Fishing Institute. In particular, he summarized the history of the conflicts between the Japanese commercial longline fishery for tunas and billfishes and the recreational fisheries in the Western Hemisphere, and how some of the problems were resolved. Finally, Mr. Stroud stated more funds were needed for game fish research and how this might be achieved.

$\mathrm{Mr}$. Squire indicated the type of catch and effort data scientists need from the angler. He outlined the type of surveys he makes on an annual basis for the eastern Pacific Ocean area. He also emphasized the need to know how much effort (time) is deployed which results in no catch.

Captain Parker commented that he believed the charter boat captains and crew can provide a lot of good data for the scientists, both on the fish and the environment, if only they took the time to record it. He was also very concerned about the lack of revenue from the sale of the fish following the mercury problem, as this is a serious economic problem in the Hawaiian charter boat industry. There was a very interesting discussion of the hookless lure, which might be useful for tagging purposes as it causes no damage to the fish, apart from other conservation aspects.

The general discussion ranged widely, both on points raised by the panelists and from the floor. The most important related to requests for printed information on the correct way to measure billfishes and take photographs of them for scientific purposes; detailed standardized logs for sport fishing vessels; tagging methods; international fishery agreements and the billfishes; identification of rare species like the "hatchet" marlin or "roundscale" spearfish; and the "lighting up" of billfish at certain times. There was a long and lively discussion of the merits or otherwise of the hookless lure for angling and scientific purposes, and the official position of the IGFA with regard to this device from the sportsmanship standpoint.

Mr. Chairman, with your permission, I would like to advise this group of some resolutions which the Board of Governors of the HIBT intends to consider and present in a final form at a later date. The first, in draft form, is really addressed to NMFS, which has the authority and responsibility for matters dealing with marine sport fishing throughout the United States of America: "It has been established at the International Billfish Symposium that the successful work on billfishes to date has arisen as a by-product of other research, and whereas the billfish are generally conceded to be the ultimate fishing quarry though little is known about their biology and distribution, the Board of Governors of the HIB'T resolves that the National Marine Fisheries Service be requested to focus attention on billfish research over the next 5 year period in order that a system for rational international management may be realized by a cooperative effort of all those parties involved."

The second will be a very self-serving resolution in which we suggest that the Secretary of Commerce consider appointing to the advisory committee of 
NMFS a representative from the central Pacific Ocean area.

In relation to the mercury session, which we purposely put on in the evening and at which attendance was not as good as hoped, we are addressing a resolution to the Governor of Hawaii which discusses the problems, both economical and philosophical, brought about by State prohibition of the sale of marlin. The Governor is interested in what goes on around this coast; although he is not a fisherman, he is interested in this tournament and serves as Honorary Chairman. We will ask him to direct the appropriate department to undertake studies which may lead to an economic use of the carcasses and which might meet both the economical and philosophical requirements. There may be some additional things, Mr. Chairman, which we will put in the form of resolutions and present to the Board of HIBT at the appropriate time.

A final word, Mr. Chairman, to echo the words of Captain Parker this morning, to say what a pleasure it has been to the HIBT and myself to see you all gathered here in Hawaii.
Mr. Lewis:

Thank you, Peter. This concludes the proceedings here this morning. However, I do not think we should adjourn before I have had the opportunity to thank Richard Shomura for putting together this meeting. He did a lot of hard work with a fine result. Thank you very much. The meeting is adjourned.

\section{Acknowledgment}

The editors wish to extend their thanks and deepest appreciation to the many individuals who helped to put together this Symposium. Special thanks should be accorded Dr. Robert L. Edwards, who, as Associate Director for Resource Research, NMFS, Washington, D.C., provided initial guidance and support to this Symposium. Finally, the success of the Symposium could not have been achieved without the dedication and outstanding effort extended by Mr. Robert T. B. Iversen, Regional Representative in Hawaii for the Southwest Region, NMFS. Mr. Iversen was solely responsible for handling the many arrangements that needed to be done in Hawaii to prepare for the meeting. 


\section{List of Participants}

Floyd S. Anders, Jr.

Deputy Regional Director

Southwest Region

National Marine Fisheries Service

Terminal Island, CA 90731

John L. Baxter

Staff Assistant

National Marine Fisheries Service

Washington, DC 20235

Grant L. Beardsley, Jr.

Fishery Biclogist

Southeast Fisheries Center

National Marine Fisheries Service

Miami, FL 33149

James S. Beckett

Fishery Biologist

Biological Station

Fisheries Research Board of Canada

St. Andrews, N.B., Canada

Ed Biaggini, Jr.

P.O. Box I6?

Cayucos, CA 93430

L. W. Bird

4729 E. 3rd St.

Tucson, AZ 85711

Robert Bonifacio

Illustrator, Honolulu Laboratory

National Marine Fisheries Service

Honolulu, Hl 96812

Joseph $\mathbf{W}$. Brooks, Jr.

Fishing Editor, Outdoor Life

2004 Prince George Road

Richmond, VA 23225

John G. Casey

Acting Director

Narragansett Laboratory

National Marine Fisheries Service

Narragansett, Rl 02882

Gordyn Caughlan

26 Hatfield St.

Blakehurst NSW, Australia 2221

Mavis Caughlan

11 Centre St.

Blakehurst NSW, Australia 2221

Paul Caughlan

President, Port Hacking G.F.C.

26 Hatfield St.

Blakehurst NSW, Australia 2221

Terry Caughlan

President, Game Fishing Association of Australia

I1 Centre St

Blakehurst NSW, Australia 2221

John R. Chibnall

P.O. Box 1228

Auckland, New Zealand

Sandy Colvin

910 Ala Moana Blvd. \#211

Honolulu, HI 96814

John Corbin

Hawaii Institute of Marine Biology

University of Hawaii

Kaneohe, HJ 96744
William L. Craig

Fishery Biologist/Extension Specialist

Southwest Region

National Marine Fisheries Service

Terminal lsland, CA 90731

David Cupka

Fishery Biologist

South Carolina Marine Resources Center

Charleston, SC 29412

Donald P. de Sylva

Associate Professor of Marine Science

University of Miami

Miami, FL 33149

H. J. Delohery

International Representative

I.G.F.A.

265 Mona Vale Road

St. lves 2073, Australia

James Delohery

32 Railway St.

Chatswood 2067, Australia

Harry L. Fierstine

Biological Sciences Department

California State Polytechnic College

San Luis Obispo, CA 93401

Jack Fischer

P.O. Box 822

Kailua-Kona, HI 96740

Peter S. Fithian

Chairman, Hawaiian International Billfish Tournament Honolulu, HI 96815

Harry Foehner

Outdoor Writer

Unofficial Representative

Texas International Fishing Tournament

Drawer 2626

Harlingen, TX 78550

Peter Goadby

Governor, Hawaiian International Billfish Tournament

Sydney NSW, Australia

Eugene M. Grabbe

Manager, Hawaii State

Center for Science Policy and Technology Assessment

Department of Planning and Economic Development

P.O. Box 2359

Honolulu, HI 96804

Doc Halliday

P.O. Box 13I1

Kailua-Kona, HI 96740

Elwood K. Harry

Executive Vice-President

International Game Fish Association

Fort Lauderdale, FL

Frank J. Hester

Director, Honolulu Laboratory

National Marine Fisheries Service

Honolulu, HI 96812

David H. Hopton

P.O. Box 1442

Cairns, Australia

John Jaea

98-263 Aiea Kai Place

Aiea, Hl 96701 
Robert T. B. Iversen

Southwest Region Representative

National Marine Fisheries Service

P.O. Box 3830

Honolulu, HI 96812

John $H$. Izatt

P.O. Box 610

Caims, Queensland 4870, Australia

J. C. Johnston

27 Wootoona Tce, St. Georges

South Australia 5064

Richard W. Johnston

5575 Pia St.

Honolulu, Hl 96821

John W. Jolley, Jr.

Florida Dept. Nat'l Resources

Marine Research Laboratory

P.O. Drawer "F"

St. Petersburg, FL 33731

James Joseph

Director, Inter-American Tropical Tuna Commission

Scripps Institution of Oceanography

La Jolla, CA 92037

Yoshiharu Kato

President, Asuka Industries, lnc.

Tokyo, Japan

Arthur G. Kay

No. 13 Belvedere St.

Epson Auckland 3, New Zealand

Hon. Shunichi Kimura

Mavor, County of Hawaii

Hilo, Hl 96720

R. W. King

P.O. Box 890

Balboa, Canal Zone

W. L. Klawe

Senior Scientist

Inter-American Tropical Tuna Commission

Scripps Institution of Oceanography

La Jolla. CA 92037

Hiroyo Koami

President. Institute of Sea Sphere

Kanagawa-Ken, Japan

Albert C. Kolbye, Jr.

Deputy Director

Bureau of Foods

U.S. Food and Drug Administration

Washington, DC 20204

Sheila Koyama

RR \#1, Box 364

Holualoa, HI 96725

Ritchie Kunichika

$145.3 \mathrm{~B}$ Glen Avenue

Wahiawa, $\mathrm{HI} 96786$

Jeffrey $M$. Leis

Hawaii lnstitute of Marine Biology

University of Hawaii

Kaneohe, HI 96744

Elizabeth W. Leis

Hawaii Institute of Marine Biology

University of Kawaii

Kaneohe, HI 96744

Dudley C. Lewis

Governor, Hawaiian International Billfish Tournament

Honolulu, HI

Leo Longazamina

I.G.F.A.

Tahiti
Henry Lyman

Publisher, Salt Water Sportsman

10 High Street

Boston, MA 02110

Bill McGee

Box 826

Kealakekua, $\mathrm{Hl} 96750$

Richard E. Marland

Interim Director

Hawaii State Office of Environmental Quality Control

Honolulu, $\mathrm{HI}$

Joaquin Arvizu Martinez

Biologist, Instituto Nacional De Pesca

Chiapas 121, Mexico 7 D.F.

Mexico

Charles O. Mather

Professor of Biology

Los Angeles City College

Los Angeles, CA 90029

Frank J. Mather III

Associate Scientist

Woods Hole Oceanographic Institution

Woods Hole, MA 02543

Walter M. Matsumoto

Fishery Biologist

Honolulu Laboratory

National Marine Fisheries Service

Honolulu, Hl 96812

Howard E. McHealy

P.O. Box 185

Kailua-Kona, HI 96740

Patricia Medvick

Department of Oceanography

University of Hawaii

Honolulu, HI 96822

Nigel R. Nerrett

National Institute of Oceanography

Wormley, United Kingdom

John M. Miller

Assistant Professor

Hawaii Institute of Marine Biology

University of Hawaii

Kaneohe. HI 96744

Frank T. Moss

Editor, Sportfishing Annual

New York. NY 10036

Eugene L. Nakamura

Director, Panama City Laboratory

National Marine Fisheries Service

Panama City, FL 3240

Izumi Nakamura

Acting Director, Fisheries Research Station

Kyoto University

Kyoto, Japan

John J. Naughton

Honolulu Laboratory

National Marine Fisheries Service

Honolulu, HI 96812

Daphne Vielsen

International Representative

I.G.F.A.

P.O. Box 808

Cairns N.Q., Australia 4870

Ed Nuchley

457 Puahuula Pl

Kaneohe, HI 96744

George S. Paika

P.O. Box 38

Kailua-Kona, HI 96740 
Ernest William Palmer

I.G.F.A. Rep.-Australia

Judge, Hawaiian International Billfish Tournament

Member, Deep Sea Mining Committee of U.N.

29 Tarlton St., Somerton Park

South Australia 5044

George Parker

P.O. Box 38

Kailua-Kona, HI 96740

William J. Richards

Fishery Biologist

Southeast Fisheries Center

National Marine Fisheries Service

Miami, FL 33149

Vicky Lynn Ridge

Research Assistant

Hawaii Institute of Marine Biology

University of Hawaii

Box 1067

Kaneohe, HI 96744

Luis R. Rivas

Fishery Biologist

Panama City Laboratory

National Marine Fisheries Service

Panama City, FL 32401

Jim Rizzuto

Kamuela, HI 96743

C. Richard Robins

Professor of Marine Science

University of Miami

Miami, FL 33149

Catherine H Robin

University of Miami

Miami, FL 33149

Philip M. Roedel

Director, National Marine Fisheries Service

Washington, DC 20235

[Presently Coordinator of Marine Recreation

Programs for NOAA]

William F. Royce, Assoc. Dir.

Office of Resource Research

National Marine Fisheries Service

Washington. DC 20235

Michael Santerre

Hawaii Institute of Marine Biology

University of Hawaii

Kaneohe, Hl 96744

Bud Sennett

Box 1104

Kailua-Kona, HI 96740

Richard S. Shomura

Director, Tiburon Fisheries Laboratory

National Marine Fisheries Service

Tiburon, CA 94920

[Present address:

Director, Honolulu Laboratory

National Marine Fisheries Service

Honolulu, HI 96812]

Marjorie C. Siu

Secretary, Honolulu Laboratory

National Marine Fisheries Service

Honolulu, Hi 96812

Robert A. Skillman

Fishery Biologist, Honolulu Laboratory

National Marine Fisheries Service

Honolulu, HI 96812
Albert C. Smith

Assoc. Prof. of Biology

Div. of Natural Science

Univ. of Hawaii at Hilo, Hilo College

P.O. Box 1357

Hilo, HI 96720

Valentin Sokolov

Fishery Biologist, Instituto Nacional de Pesca

Chiapas 121, Mexico 7 D.F.

Mexico

Michelle Rufus Spalding

Kailua.Kona, HI 96740

James L. Squire, Jr.

Fishery Biologist, La Jolla Laboratory

National Marine Fisheries Service

La Jolla, CA 92037

H. C. Stecker

P.O. Box 400

Kailua-Kona, H1 96740

Richard H. Stroud

Executive Vice-President

Sport Fishing Institute

Washington, DC 20005

Paul J. Struhsaker

Fishery Biologist, Honolulu Laboratory

National Marine Fisheries Service

Honolulu. HI 96812

J. Thomas Stuart III

Special Asst. to the Marine Affairs Coordinator, Governor's Office

State Capitol

Honolulu. HI 96813

Michio Takata

Director, Hawaii State Division of Fish and Game

Dept. of Land and Natural Resources

Honolulu. HI 96813

Curt is A. "Bud" Thompson

75 Kailea Place

Kailua, HI 96734

S. Noel Tibbo

Acting Assistant Director

Biological Station

Fisheries Research Board of Canada

St. Andrews, N.B., Canada

Shoji Ueyanagi

Fishery Biologist

Far Seas Fisheries Research Laboratory

Shimizu, Japan

Dan Wallace

3015 Kiele Aven'se

Honolulu, HI 96815

Les Walls

P.O. Box 278

Haleiwa, HI 96712

W. B. Wardily

P.O. Box 326

Wahiawa, HI 96786

Paul G. Wares

Fishery Biologist

Tiburon Fisheries Laboratory

National Marine Fisheries Service

Tiburon, CA 94920

Billy Watson

868 Center

San Luis Obispo, CA 93401

William Watson

Hawaii Institute of Marine Biology

University of Hawaii

Kaneohe, Hi 96744 
F. Williams

STOR Scripps Institution of Oceanography

P.O. Box 109

La Jolla, CA 92037

[Present address:

Division of Fisheries and Applied Estuarine Ecology

Rosenstiel School of Marine and Atmospheric Science

University of Mliami

10 Rickenbacker Causeway

Miami, FL 33149]

\section{Peter Wilson}

P.O. Box 75

Kailua-Kona, HI 96740

George A. Wooller

P.O. Box 28-159

Auckland 5, New Zealand

C. Yap

1136-A - 20th Avenue

Honolulu, Hl 96816
E. Yee

801 Kaheka Street

Honolulu, HI 96814

Howard O. Yoshida

Fishery Biologist

Honolulu Laboratory

National Marine Fisheries Service

Honolulu, HI 96812

Richard E. Young

Asst. Prof., University of Hawaii

2525 Correa Road

Honolulu, Hl 96822

Heeny S. H. Yuen

Fishery Biologist

Honolulu Laboratory

National Marine Fisheries Service

Honolulu, HI 96812 


\title{
ANNEX 2
}

\author{
Welcoming Address \\ by \\ The Honorable Shunichi Kimura \\ Mayor, County of Hawaii
}

Thank you very much, Dick. This must be a very competent kind of gathering, because for once they got me a maile lei short enough to fit my stature.

But you know I'm particularly happy to have Mr. Roedel and Dick and all of you here at this very distinguished gathering of scientists and environmentalists and sportsmen. 1 do want to make a confession to all of you though, that the only knowledge that I have about fishing is that I do get seasick and by the food that I eat; I eat raw fish by the tons and I have a 10-gallon aquarium in my house and this is the extent of my abilities as far as the fisheries are concerned.

But I do want to, like all of the others, extend a very warm welcome to all of you on this Island; we're very privileged to have this kind of distinguished group of experts in the marine billfish area. However, I'm going to leave to Mr. Roedel the overview and the technical side because I know absolutely nothing about this area. But I do want to share with you some of the folks that the Island of Hawaii has in the areas of research and scientific endeavor.

I have a strong feeling that if this Island is going to depend upon agriculture and the visitor industry, I suspect many of us would be leaving this Island to live in San Francisco or La Jolla or some other swinging place throughout the country: what we really want on this Island is a combination. If we want agriculture, we want agriculture plus the expertise in tropical research in the agricultural area; if we have the visitor industry, we want the visitor industry not solely for itself but because we think that we can combine a very unique destination area. For instance, in this Kona area with Peter Fithian's imaginative leadership and the big-game fishing area, combined with the things such as Mr. Roedel and Dick and Bob are doing here on the Symposium I think creates a particularly unique and particularly exciting kind of a visitor destination area. And so we'd like to extend all of the best of resources that we have to develop that kind of scientific and research capability. As you know, NOAA already has a major facility up on Mauna Loa with the Atmospheric Research group. Up on Mauna Kea, the tallest mountain that we have, we also have the NASA people with their 85 -inch telescope and the French coming in with their 150 -inch telescope within a few years. In terms of geothermal kinds of research we obviously have a great expertise in volcanology; we'll try to extend this and participate with the Atomic Energy people and the people in the National Science Foundation and the other agencies so that we can have major research in the area of geothermal power and energy. We have approximately about one quarter million dollars in appropriations from the State and County governments for this particular kind of energy research. And if we look at the rains that fall on these Islands we have a fairly competent area in terms of cloud physics kinds of research at the University of Hawaii Hilo Campus. And we can go on and on. What we've done really is take all of the natural resources that are found on this Island and tried to develop them so that we can have fairly substantial research and development kinds of facilities on this Island. As I welcome you here I'd like to also ask your support, your help, and your counsel in how to develop the fisheries kind of expertise on this Island, in terms of developing facilities, in terms of inviting you people back again when you have additional information and additional need to get together. I've already asked Mr. Roedel for his assistance and he's already given me advice as to how we can go about it to try to extract field station and field facilities and possibilities of a common research station here on the corner area on the Island of Hawaii. We're pushing for a retreat, a scientific retreat area up on the northern part of this Island, so that we can have scientists come here to do research and, of course, to have a retreat in an area where they can quietly work on their cases and their particular kinds of endeavors.

So what we hope to do really on this Island, then, is to create a tremendous expertise in tropical agriculture, both in the business end and in the area of research. We also want to create a very unique visitor area, an area that's not only wonderful in terms of recreational visits, but also in this kind of a tremendous combination of the Peter Fithians and the National Marine Fisheries Service. Of course, we want to extend our research and development abilities throughout the Island of Hawaii and make these indeed one of four major industries. But in trying to achieve all of these very lofty and great expectations for this 1sland, we are going to need the help, the expertise, and the counsel of all of you. I hope that I can ask your help in trying to attract to these Islands various scientific conferences and symposiums and retreats because we do not have that much expertise or that much capacity in reaching all of the scientific and research groups that we need to come to this lsland to hold their deliberations.

So again I want to thank you very much; we're very happy to have all of you here. It is a great privilege for all of us to have such a gathering of all of the experts in the areas of billfish and marine fisheries. I hope that if there is anything that we can do to make your stay here that much more pleasant or enjoyable please do not hesitate at anytime to call upon myself. Thank you very much. 


\title{
ANNEX 3
}

\author{
Opening Address \\ by
}

Philip M. Roedel

Director, National Marine Fisheries Service

National Oceanic and Atmospheric Administration

U.S. Department of Commerce, Washington, DC

Mr. Chairman, Mayor Kimura, distinguished guests, participants in the First International Billfish Symposium. It is a great pleasure to be with you today, for the opening of what I am sure will be a most eventful Symposium.

I want first to bring you greetings from the Administrator of the National Oceanic and Atmospheric Administration, Dr. Robert M. White, who asked that I extend his best wishes to all of you.

This is a particularly happy occasion for me. I have many pleasant memories of Hawaii, extending back to the Pacific Tuna Biology Conference held in Honolulu in 1961 and including the Hawaii Governor's Conference on Central Pacific Fishery Resources in Hilo in 1966 in which, I recall, Mayor Kimura participated. There have been others as well, but these two meetings illustrate the importance attached to fishery resources both by officials of the State of Hawaii and by the Federal Government. The Symposium we are opening today is, I believe, a worthy successor to its forerunners.

This is the first scientific Symposium sponsored by the National Marine Fisheries Service since its founding nearly 2 yr ago. I think it is especially appropriate that the subject is a group of fishes of primary concern in the United States to sport fishermen. I say this because of the origin of NMFS, which was formed in 1970 as a component of the National Oceanic and Atmospheric Administration (pursuant to Reorganization Plan No, 4 of 1970, 84 Stat. 2090). The constituent parts of the new service came primarily trom the former Bureau of Commercial Fisheries in the Department of the Interior. The service also includes, however, the migratory marine game fish program of the Bureau of Sport Fisheries and Wildlife, and this gives the new organization a far different role from that of its chief predecessor. The Symposium helps emphasize this: The concern of NMFS for the resource as a whole, and its responsibility to all user groups, be they sportsmen, commercial fishermen, or someone else.

The idea of an International Billfish Symposium actually dates back to the late 1960's when Richard Shomura was stationed at our Honolulu Laboratory. He maintained his interest when he transferred to the mainland in 1970, and he organized a workshop on billfishes which was held at the Tiburon (California) Fisheries Laboratory in 1971. Final plans for the Symposium were developed at that workshop.

The Symposium agenda is comprehensive and substantive, and I want to congratulate Mr. Shomura, who served as Chairman of the Organization Committee, and the other committee members, Messrs. Iversen, Squire, and Williams, for a job well done.

1 want at the same time to express my appreciation to the cosponsors (the County of Hawaii, the Hawaiian International Billfish Tournament, and the State of Hawaii) for all they have done to make this event possible, and to the Food and Agriculture Organization of the United Nations for its support.

Why a symposium? There are two primary reasons. First, billfish research in most parts of the world is a by-product of other activities primarily in areas where there is an active tuna research program. Scientific study of the billfishes has thus been relatively limited. Most of what we know about the size and distribution of stocks, and effects of fishing upon them must be inferted from catch statistics from the fishing nations, primarily dapan.

Because of this generally secondary role, communication among scientists on a worldwide basis has been something less than adequate. This Symposium is a step in the right direction toward meeting what we regard as an urgent need for scientists to exchange ideas and viewpoints. Second, and of equal importance, the Symposium will permit interaction, also on a worldwide basis, between scientists and sport fishermen with respect to a major high-seas fishery, something that appears to be both unique and long overdue.

Let me turn now to the fishery. While man has harvested billfish since before recorded history and has taken them recreationally for many decades, the total catch has been relatively small until fairly recently.

We have, since World War II, seen a marked expansion of longline fishing for hitherto relatively unexploited high-seas stocks. Before that time, billfish had been harvested lightly, primarily because they are nonschooling species scattered over wide areas, and hence were not taken efficiently before the ad. vent of longline gear.

The most recent statistics published by the Food and Agriculture Organization of the United Nations show that the global commercial catch in 1970 was about 101 thousand metric tons (Table 1). Of this, about 70 thousand were taken in the Pacific Ocean, 20 thousand in the Atlantic Ocean, and 10 thousand in the Indian Ocean. While some 20 nations reported billfish catches in 1970, Japan continued to dominate with some two-thirds (67 thou. sand metric tons) of the total. Taiwan ranked second, with over 15 thousand. Canada, in third place, took under 5 thousand. The United States was eighth, with about 700 metric tons. The U.S. commercial fishery is relatively insignificant; it is sport fishing that is the critical item in this country. The total sport fishing catch is unknown, but it unquestionably adds considerably to the total harvest.

Sport fishing for billfishes takes place in many parts of the world: East Africa, Australia, American Samoa, Hawaii, California, the Pacific Ocean waters of Mexico, the Gulf of Mexico, and several areas in the Atlantic Ocean. Commercial fishing is even more widespread but it is basically a high seas fishery. The sportsmen generally operate much closer to shore. This is not to say there is not or has not been conflict for there has, particularly off the west coast of Mexico and in the Gulf of Mexico, where the longline fishery did intrude into some prime big-game fishing grounds. The big-game anglers watched this incursion and noted the reports of increased catches of billfishes. They understandably became alarmed for the future of their sport, and indeed for the future of the resource itself.

What about economics? Hawaij offers a good example of the relative magnitude of sport versus commercial fishing for billfishes in the United States. In 1968 some 35 charter boats earned an estimated $\$ 700,000$ in charter fees. The commercial value of billfishes landed by the small longline fleet operating in Hawaii that vear was about $\$ 225,000$. In 1970 , the value of commercial landings of billfishes was about $\$ 290,000$, but in 1971 it fell to less than $\$ 150,000$. In 1971 , the charter boats numbered about 48 , and the earn. ings from sport fishing for billfishes were about $\$ 1.3$ million. Obviously in Hawaii, revenue from recreational fishing for billfishes far exceeds the economic gains from conventional commercial fishing enterprises. Similar circumstances tikely prevail elsewhere. (The marinas and vessels supporting a charter fishery are also commercial enterprises, but they are not identified as commercial fishing enterprises in the usual sense of that term.)

We are thus dealing with a group of oceanic fishes prized equally by sportsmen and by commercial fishermen. They comprise a resource of unknown size, but the rapid growth of the global fishery in itself is enough to give us cause for concern. Through this Symposium, we hope to get a better fix on the present state of knowledge and where we should devote our major efforts in the next few years, if we are to understand the dynamics of these severa! species

Assuming we have or can soon attain sufficient knowledge of the status of the stocks to permit rational recommendations for management, what then? If analyses of available data indicate a need for reduction in fishing effort on some or al! of the stocks, how does one proceed? We are faced with the need to understand some extremely complex biological systems, and with the equally difficult matter of solving political and social problems of allocation among nations and among user groups within nations. Except in the Atlantic Ocean, where billfishes are included in the frame of reference of the International Commission for the Conservation of Atlantic Tunas (ICCAT), no mechanism for international action exists.

There is, of course, a Law of the Sea Conference (LOS) scheduled for Geneva in 1973. A number of preliminary meetings have been held, and as a matter of fact, a preparatory meeting is now taking place there with strong representation by knowledgeable fisheries people. On the U.S. side, industry

Table 1.-World catch of billfishes by waters, 1970.

Species Pacific Atlantic $\begin{aligned} & \text { Indian } \\ & \text { Ocean Total }\end{aligned}$

Sailfish -...-...-.-.-Thousands of Metric Tons--............ 9.1 1.0 I.I 11.2

Blue marlin

Black marlin

Striped marlin

$$
18.8
$$

4.1

White marlin

22.1

$$
0
$$

3.1

Broadbill

$$
\text { swordfish }
$$

0

$$
\text { Total }
$$$$
70.4
$$

Source: FAO Fisheries Y'earbook 1970 
(not sportsmen) has had considerable input into the preparatory meetinga, and NOAA and NMFS have had top level people on the U.S. Delegation.

The present U.S. position on fisheries was articulated most forcefully by Ambassador Donald L. McKernan at last spring's preparatory meeting held at the United Nations in New York.

To quote Mr. McKernan, this position is " . . based on a species approach, that is, on the principle that the management and harvesting of fisheries should be governed by the biological distribution and migration of fish stacks, rather than by arbitrary jurisdictional boundaries." The position thus depends on the fact that some species are distributed along coastlines, others are principally migratory on the high seas, while still others are spawned in freshwater and migrate to the coastal areas and onto the high seas. These three categories of coastal, high seas, and anadromous stocks form the basis for the species approach to international management.

Marine species in general and billfishes and tunas in particular do not respect the lines drawn in the ocean by governments about their coastlines to delineate their territorial seas or contiguous fishing zones. This is one of the reasons fisheries is probably the thorniest of all the LOS issues.

The United States species approach calls for the coastal fishes, such as anchovies, cod, and hake, to be managed by the adjoining country, with that country having a preference in harvesting those stocks. If the adjoining country did not catch all the harvestable surplus of a given stock, other countries could take the remainder. The anadromous species, such as salmon, would be managed throughout their migratory range by the coastal country.

The high-seas species, such as tunas and billfishes, would be managed through an international arrangement, either of a regional or worldwide nature, perhaps similar to or based upon existing international conventions for conservation and management of high-seas resources. Existing conventicns of this nature include the very successful Inter-American Tropical Tuna Commission in the eastem Pacific Ocean, and the more recently established ICCAT (which includes billfishes and to which I have already alluded)

The whole question of how best to manage high-seas stocks thus remains unresolved, and we cannot hope for resolution until we know the outcome of Geneva. We can hope that a rational scheme will be forthcoming and that by the time it is effective we will be well on the road toward obtaining the scientific knowledge basic to its implementation.

I want to turn briefly to a serious problem facing us particularly in the United States. I refer to heavy metals found in small amounts in many fishes, and for one of which, mercury, the U.S. Food and Drug Administration (FDA) has established a guideline of 0.5 parts per million. Certain fish. among them billfish and particularly swordfish, frequently exceed this tolerance. Hawaii offers a good example of the impact of mercury on fishing.

Until the heavy metal problem arose in 1970, Hawaii had no difficulty in disposing of the billfish sport catch, for the fish were used as food ashore. Mercury at levels above the FDA guidelines changed this, and both sport and commercial fishermen are now faced with determining how to dispose of the catch.

Because of the intense local and worldwide interest in the subject, the scientific papers bearing on it will be summarized at a special public evening session at which Dr. Albert C. Kolbye, Deputy Director, Bureau of Foods, U.S. Food and Drug Administration, will speak.
While this is the first time a scientific meeting has been held in concert with the Hawaiian International Billfish Tournament, it is the 14th year for the tournament. Mr. Peter Fithian, its chairman and a participant in the Symposium, is one of the founders of the tournament which has done 80 much to further sport fishing in Hawaii.

Tournaments of this sort are becoming even more popular and more numerous. On the Pacific coast, we have the San Diego Marlin Club Invitational Light Tackle Tournament. A swordfish tournament will be held for the first time this September near Santa Barbara, Calif. Several southern California billfish clubs stage tournaments about the tip of Baja California, which with the west coast of Mexico from Acapulco to Guaymar, has long been an internationally famous billfish area. One of the pioneer tournaments is that conducted by the Tura Club of Avalon, the world's oldest billfiahing club. It was founded in 1898 by Dr. Charles F. Holder, the originator of the Tournament of Roses in Pasadena, Calif. The organization began as a bluefin tuna club and held its first tournament in 1899. It expanded to include striped marlin in 1903, and recorded its first swordfish on rod and reel in 1913.

All along the Atlantic and Gulf coasts, major billfish tournaments are held annually: from Nantucket and Cuttyhunk, Mass.; Cape May, N.J.: Hatteras, N.C.: Cape Canaveral, Palm Beach, Miami, and Panama City. Fla.; New Orleans, La.; Galveston, Tex.; San Juan, P.R.; and the islands of Cozumel and Mujeres off Yucatan, Mexico. This does not pretend to be a complete list, but it does show the widespread popularity of these tournaments.

No such recitation would be complete without mention of the International Game Fish Association (IGFA), founded over 20 yr ago by Mr. Michael Lerner, who is today its chairman. One of the objectives of this organization is to keep world records of saltwater game fish. The IGFA has as members the competitive clubs around the world and is governed by an international com. mittee. Its contributions to marine game fishing are legendary.

I want to touch on cooperative research efforts. We have for several years been conducting a cooperative tagging project off the west coast of Mexico in an effort to monitor the impact of fishing, including the Japanese longline fishery, on billfish stocks. We have expanded our studies this year to utilize the catches made during tournaments to give us additional information on stock and recruitment in the South Atlantic Ocean and Gulf of Mexico. The cooperative game fish tagging program that Mr. Frank Mather of the Wooda Hole Oceanographic Institute has fathered for more than $20 \mathrm{yr}$, will be supported substantially by NMFS as a part of our expanded game fish program. Information to be gained from these studies is vital to our mission of representing all U.S. fishery interests, sport and commercial, in negotiations with other high-seas fishing nations.

In closing. I want to propose that this Symposium be dedicated to the memory of two men, one a scientist, one a sportsman, who did much to further our knowledge of the ocean and of fisheries: Dr. O. E. Sette and Col. John K. Howard.

Mr. Chairman. Mayor Kimura, I believe we are opening a Symposium that will have a lasting value. I appreciate the opportunity to be a participant. Aloha and mahalo. 


\title{
ANNEX 4
}

\author{
Address
}

by

Michio Takata

Director, Division of Fish and Game

Mr. Chairman, it is certainly a pleasure to see such an array of scientists and sportsmen from all corners of the earth assembled here for this Symposium. I would like to merely add our welcome to that extended by Tom Stuart, on behalf of the Division of Fish and Game of the Department of Natural Resources. I extend my warm welcome and aloha to you all and although we are cosponsors of this Symposium, I must admit that the National Marine Fisheries Service did most of the hard work that went into organizing the Symposium. The National Marine Fisheries Service has put together a fine looking program and I look forward with you to a very in. teresting and productive 3 days of discussion and exchange of ideas and information about the billfishes. I wish you all a very pleasant visit. Mahalo.

\section{ANNEX 5}

\author{
Address \\ by \\ J. Thomas Stuart III \\ Special Assistant to the Marine Affairs Coordinator \\ State of Hawaii
}

I am happy to be representing Dr. John Craven and the Office of the Marine Affairs Coordinator here today.

Increasingly we are aware of the importance of oceanic studies in the future of all nations, but especially those that border the great oceans of our planet.

This week's Symposium is a strong reflection of Hawaii's deepening involvement in our total understanding of one of man's least understood frontiers.

Hopefully, the future will see many more such gatherings as today's. For no matter how specific the subject area, all new findings will benefit more than a few in our continuing quest to find the solutions to problems of pollution, new food resources, better use of all marine resources-not least of all the more effective and pleasurable use of our leisure time.

Thank you. 


\section{ANNEX 6}

\section{Address}

by

Peter Fithian, Chairman

Board of Governors, Hawaiian International

Billish Tournament

Aloha. I cannot tell you how delighted the billfish tournament is that you are all here. 1 do not think that you should all stay in one room at one time because if anything happened 1 do not know who else would be working on the billfishes. Believe me this is very important to a lot of sportmen like myself. I am sure in this room on Saturday morning that you will get many questions and ask many questions that could throw a lot of light on a lot of subjects which 1 am sure are near and dear to your hearts and ours. I sincerely hope that as a result of the meetings here between scientists and sportsmen, we will be able to provide all the channels of communication which I think have been sorely lacking in this field. I have no background in science at all. I managed normally to flunk chemistry and physics annually for a number of years, but 1 do have some feel of how sport fisheries are organized in this part of the world. I am delighted that so many of you have come to Kona. I extend you a warm welcome to come to the pier, wearing your badge please, as it gets a little hectic down there. If there are things you want to do with the fish, please let us know so that we can make arrangements. After all we are told you do not get them every day in your laboratory. We had nine marlin as of noon today, so that means possibly we will have another half dozen before the afternoon is over. Enjoy yourself, this is one of the great fishing areas in the world and one of the very pleasantest places to be located. Aloha.

\section{ANNEX 7}

Text of Cable

from

F. E. Popper, Assistant Director-General

Department of Fisheries

Food and Agriculture Organization

of the United Nations

Rome, Italy

"FAO extends best wishes for successful symposium which will contribute greatly to improve knowledge on billfish biology and resources signed Popper Assistant Director-General (Fisheries)." 


\section{ANNEX 8}

Potential Health Hazards of Mercury in Fish

by

Albert C. Kolbye

Deputy Director, Bureau of Foods

and

Acting Director, Office of Science,

Food and Drug Administration

Washington, DC

At the outset, I should like to emphasize several points that I would like you to keep in mind throughout my presentation. I will be talking initially about the effects on health caused by excessive exposures to methylmercury. In the normal course of events there is very little, if any, likelihood that people living in the United States would receive exposures comparable to the Japanese villagers later described. However, it is necessary to describe what can occur in the extreme if we are to understand the present perspective on mercury as a potential health problem in the United States and why the FDA has set a guideline for mercury in fish.

There is no reason for public alarm or distortion of risk by magnification beyond the true perspective, because no health crisis is imminent from mercury in fish. We should understand, however, that there is reason to exercise prudence and caution, hence the existence of the FDA guideline. Towards the end of my talk I will go into the guideline itself and explain some of the reasoning behind it. I would also like to emphasize that there has been no fully documented instance of a U.S. resident suffering clinically evident mercury poisoning from exposures to mercury in fish. However, the occasional presence of subclinical brain damage from excessive exposures to mercury in fish has not been excluded, particularly in relation to children of mothers who eat unusually high amounts of fish containing substantial amounts of mercury in the form of methylmercury. One reason for the guideline is to protect pregnant women from inadvertently damaging their unborn children.

The potential health hazards of excessive exposures to mercury in fish primarily relate to the particularly toxic form of mercury most frequently encountered in both freshwater and pelagic fish. Methylmercury is the particularly toxic organic form which, because of its biochemical charecteristics, is almost totally absorbed from the human gastrointestinal tract and circulated through the blood to the various organs and tissues where a range of harmful effects can potentially occur. In contradistinction to either inorganic or other organic forms of mercury when ingested, methylmercury can more readily penetrate the "blood-brain barrier," enter the brain tissue, and cause irreversible damage to brain cells. If methylmercury were easily and quickly excreted from the human body, then occasional exposures to foods containing higher than normal background levels of methylmercury would present little reason for public health concern. However, such is not the case with methylmercury.

When we speak of the biological half-life of a substance, we refer to that period of time necessary before the body can rid itself of $50 \%$ of the initial amount present. The biological half-life of methylmercury in humans has been determined by observational studies on exposed humans and by direct experimentation on human volunteers with orally administered radioactively labeled methylmercury. The observational results indicate that 69-70 days and 76-83 days represent the biological half-life for red blood cells and plasma, respectively, after ingestion of fish contaminated with methylmercury. The biological half-life of methylmercury-203 as determined by total body measurement of the volunteers was 70-74 days.

Why should we be concerned with this biological half-life of 70 days? The practical significance relates to the problem of accumulation in the body if intake exposures are significantly greater than excretion. Please note that various organs such as brain tissue may have a longer half-life than 70 days. while other tissues may have a shorter half-life, thus resulting in the average net half-life of 70 days. Our primary concern is with accumulation of methylmercury in the brain and at this point I should stress not only the adult human brain but more importantly the developing fetal brain. Methylmercury easily crosses the human placenta into the blood of the human embryo as it develops in utero. As the human embryo goes through the various stages of development before birth of the infant, its developing tissues are much more sensitive to damage from toxic substances than are adults. This is especially true for fetal brain tissue which can be exquisitely sensitive hy comparison.

Accumulation of methylmercury in the human body has been documented many times as to the occurrence of the phenomenon and the brain damage it has caused in humans unfortunately exposed to highly contaminated foods. Additionally, we have other information from accidents and industrial exposures of pesticide workers. The results of experimental exposures of test animals, including monkeys, corroborate the cause-effect relationships of methylmercury to brain damage in human aduits and infants. I will try to summarize the most significant points of information for you.
Two episodes occurred in Japan involving fairly large numbers of people and the opportunity to perform in-depth studies. The villages of Minimata and Niigata suffered similar problems during the 1950's and early 1960's. Fish and shellfish in the areas contained high levels of mercury (almost entirely in the form of methylmercury) resulting from local pollution by industrial sources. As you know, the japanese consume more seafood in their average diet than we do. There were 121 cases of human methylmercury poisoning reported in Minimata of whom 46 died. Among the 121 patients, there were 23 infants and children who were affected with a severe cerebral palsy-like disease from 1954 to 1959 . The important thing to remember here is that none of these infants and children so affected had consumed any of the contaminated seafood themselves. Most were born with the affliction not only being clinically obvious but in many cases, severe. Some of the severely afficted have never seen, heard, spoken, or made a purposeful motion in their lives and in the figurative sense they exist as human vegetables. Others are less affected but still severely handicapped. Now comes the "hooker"-their mothers appeared to be normal. There were no clinically obvious signs of poisoning among the mothers at that time, yet their bodies had acted to accumulate methylmercury which was transferred through the placenta to their own children while the children were developing embryos in the womb.

An additional 47 people, 6 of whom died, were reported from the Niigata episode. I visited Japan in 1971 to perform a follow-up evaluation on the Minimata villagers and learned that more cases have been recognized than had been reported earlier, apparently due to the delayed effects of methylmercury poisoning not being recognized earlier in some of these patients. One case was of particular interest. It involved a physician who obviously would be more likely to recognize the early symptoms of mercury poisoning which include tremor, nervousness, and impairment of both vision and coordination. He celebrated one evening and drank too much. Instead of waking up with a hangover, he awoke the next morning with clinically obvious symptoms of mercury poisoning and died 10 days later from the disease. At autopsy, his brain showed advanced tissue damage with all the typical brain tissue pathologic findings of mercury poisoning. Apparently, he had been able to compensate partially for the damage in brain function. Since the onset of the disease in adults can be gradual he was able to compensate enough to live a fairly normal life until additional brain damage from high alcohol consumption tilted the delicate balance of compensation and his brain could no longer function well enough.

Similar advanced brain damage has been noted to result in Scandinavia after accidental short-term industrial exposure to alkyl mercuric pesticides in which the worker involved died 20 yr later from an unrelated cause without additional mercury exposures. There have been other unfortunate human experiences with methylmercury poisoning dating as far back as the original laboratory workers who first synthesized the compound and as recently as the current massive poisoning outbreak in Irac due to the wrongful diversion of methylmercury treated seed wheat by farmers into bread.

The ahility to compensate partially for damaged brain tissue has also been noted in Swedish studies of monkeys experimentally exposed to methylmercurv. Some of the monkeys apparently were largely unaffected as far as their normal patterns of brain function were concerned, while others showed gross deterioration of brain function much earlier during the course of the experiment even though the exposures to doses of methylmercury were similar. Generally speaking, however, once a monkey showed signs of brain damage, further deterioration was very rapid with death usually following shortly. When some monkeys showed signs of advanced damage, the Swedish investigators then sacrificed several other monkeys apparently unaffected by similar exposures to methylmercury and found extensive brain damage at autopsy. Also, when monkeys apparently unaffected were allowed to live longer, symptoms then occurred with unpredictable sudden rapidity and a quick demise. Similar findings have been noted when cats and rats were studied. These were all adult animals.

There are several points that these findings bring to our attention. Severe hrain damage from excessive exposures to methylmercury may go undetected in some adults for a while but the damage has occurred even though the time of onset of clinically ohvious symptoms may vary with the particular individual. The brain damage is irreversible although partial compensation may temporarily delay onset of obvious disease. Excessive exposure to methylmercury may also contribute to early demise of brain function without 
being recognized unless specific examinatione are performed by pathologists. Excessive exposures to other toxic substances that can damage brain tissue can produce interactive effects and potentially reduce the ability of the human body to tolerate aubclinical exposures to methylmercury.

Also of interest in Minimata was the observation by public health officials that a number of teenage children in the village who were born around the time of the original episode are now experiencing difficulty in coordination when they attempt to play baseball and basketball. Others have visual im. pairment and more obvious signs. It would appear that subclinical brain damage had occurred earlier in their lives, probably before they were borm, but signs of brain damage were delayed and are now beginning to be seen.

In Niigata, the lowest blood methylmercury level associated with toxic symptoms was $0.2 \mathrm{ppm}$. This level has been exceeded by certain Swedish fishermen eating freshwater pike from streams contaminated by mercury effluents from pulp-paper operations. So far, they have not shown any obvious symptoms but further investigation is indicated and we hope autopsies are obtainable in the future.

However, the blood level at $0.2 \mathrm{ppm}$ mercury has been made the reference point that both Swedish and American health authorities use as the threshold of toxicity. Using the biologic half-life data to perform ateady-state calculations, it has been determined that a daily intake not to exceed $0.3 \mathrm{mg}$ would permit a $70-\mathrm{kg}$ (150-pound) individual to remain at or below a blood level of $0.2 \mathrm{ppm}$. Both the Swedes and the Americans determined that a 10 fold safety factor was necessary and appropriate to protect individuals with unusual susceptibilities and infants from aubclinic brain damage.

Accordingly, to maintain blood methylmercury levels at or below 0.02 $\mathrm{ppm}$, average total dietary intake of methylmercury should not exceed $30 \mu \mathrm{g}$ per day. This permits an individual to eat $60 \mathrm{~g}$ of fish at maximum permissible mercury levels (approximately $0.5 \mathrm{ppm}$ ) each day over a long period of time, without invading the safety factor and accumulating methylmercury in the body such that blood levels would exceed $0.02 \mathrm{ppm}$. We know that Americans eat less fish than do the Japanese, consequently since the average serving of fish in America approximates $210 \mathrm{~g}$, which is a little less than $1 / 2$ pound, this means that two meals of fish at guideline would use up 1 week's "ration" of methylmercury (additional exposure to inorganic mercury). Or said another way, one meal of swordfish with average mercury content at 1 ppm uses up a week's ration of methylmercury. Fortunately, most fiah from both fresh and salt waters are well below guideline. Since many people who eat fish eat several meals per week, especially "weight-watching" women during their child-bearing years, the FDA guideline exists to protect people who like to eat fish from the potential hazards of accumulating excessive methylmercury in their bodies, and especially to protect children from in utero exposures to methylmercury that could cause clinical or aubclinical brain damage. 


\title{
ANNEX 9
}

\author{
Status of Mercury Studies in Hawaii \\ by \\ Richard A. Marland \\ Interim Director \\ Office of Environmental Quality Control
}

The State of Hawail became concerned with the methylmercury in fish products in the month of April last year. By May of last year we had conducted sufficient analyses under the auspices of the State Department of Health to show that the average total mercury content of marlin entering the market in Hawaii was just over $4 \mathrm{ppm}$. These results were corroborated by the laboratory which Ms. Shultz represents here, the Pesticide Study Laboratory, At that point we asked the fishing industry of Hawaii to withhold sale of the blue marlin on a voluntary basis. This has been done ever since the request was made. It was only fair that having had this kind of cooperation from the fishing industry, the State of Hawaii should exert all possible efforts to establish whether removal of this species from the market was justified or to establish the conditions under which it could be sold. The Pesticide Laboratory of the University has been conducting analyses to determine the extent to which methylmercury is present as part of the total mercury value. There are two other efforts now going on, sponsored by the State. One of them is of such size and importance that we have requested funding from the National Science Foundation. We have not yet had an affirmative response, but this would be a 3-yr study at a cost of over $\$ 500,000$. It will include the evaluation of some 9,000 people in Hawaii who are known to have a fisheating habit. You've heard Dr. Kolbye point out that one serving of fish on the order of 7 ounces per week at $1 \mathrm{ppm}$ gives you a full week's quota of methylmercury. If you're talking about a fish of $4 \mathrm{ppm}$, you get down to something under 2 ounces a week. It is not unusual for people of Japanese ancestry in Hawaii to eat a third of a kilogram of fish a day. On this basis it becomes very important that the fish being consumed to that extent does indeed contain the lowest possible levels of organic mercury. So the study of these 9,000 people of Japanese ancestry would be conducted as an historical study to determine if there is any evidence in their medical history of an effect of mercury poisoning. There would also be another study of some 300 pcople of Japanese ancestry. This $3-y r$ study will involve a very careful monitoring of the diet of these people, examination of their medical history, and observations made by physicians. The participants would all be residents of Lanai; they are already being studied for medical deficiencies. This study, which is an extensive study planned for 3 years' duration, has not yet been started because the cost of the project cannot be met at the local level.

Recognizing that we might not be able to get a human epidemiological study mounted immediately, the University of Hawaii, Department of Animal Sciences, started a program of research in the winter in which they used swine as an experimental animal. Swine, in this case, is an excellent animal because the metabolic system of swine is almost identical to that of human beings. There are some preliminary data available now from this swine-feeding experiment. Substantially there were five groups of swine, one on a control ration of feed, another on normal feed plus 1 pound of raw fish a day, and three experimental groups in which this 1 pound of fish had added mercury of $0.5 \mathrm{ppm}, 5.0 \mathrm{ppm}$, or $50 \mathrm{ppm}$. These pigs were again subdivided because of the interesting results coming from Ms. Shultz's work so that we had half of them on organic mercury and half of them on inorganic mercury. Not too surprisingly, of those pigs that were receiving $50 \mathrm{ppm}$ of organic mer. cury, or methylmercury, none lived past 26 days. They were the only pigs on trial that died during the experiment. Pigs that were fed $50 \mathrm{ppm}$ of inorganic mercury showed liver damage and lymph node damage, and as yet we have not conducted the pathological examination of these tissues so we do not know if there was further damage. Pigs that were fed $5 \mathrm{ppm}$ of organic mercury in marlin appeared perfectly normal. Upon slaughter, hemorrhage on the periphery of the lymph nodes was noted, the lymph nodes were enlarged, and the livers had developed fatty tissue above them. There seemed, therefore, to be some gross pathology in the pigs that were fed marlin with 5 $\mathrm{ppm}$ of organic mercury. Pigs fed $5 \mathrm{ppm}$ of inorganic mercury showed no symptoms or any type of pathology other than perfectly normal growth Those that were fed the lowest level were perfectly normal, even in the case of $0.5 \mathrm{ppm}$ organic mercury. The reason for selecting these levels, of course, is to establish, as Dr. Kolbye has pointed out, the validity of a 10-fold safety factor. Dr. Knlhye will be pleased to hear that from each of these trials two of the females are heing retained for breeding purposes and they will be studied for three generations to see whether or not there is a placental transfer of mercury to the offspring. These experiments, we hope, will lead to some type of recognition of the hazard of mercury. We hope the human epidemiology experiment will lead to some type of recognition of the risk, these data again to fnrm a base upon which decisions can be made. We wish that we could say at this time that the data are sufficient to make decisions; they are not. We don't know whether there will be sufficient data. We hope, of course, it will be soon. 


\section{ANNEX 10}

Definitions and Methods of Measuring and Counting in the Billfishes (Istiophoridae, Xiphiidae)',

by

Luis Rene Rivas

\section{Abstract}

The need for definition and standardization of methods of measuring and counting in ichthyology is discussed, with special reference to billfishes. A series of measurements and counts for the latter group is proposed and methods and definitions for each are given. The body length is discussed in more detail in connection with its importance as a base length and attention is called to the need for dissection in order to ascertain accurately the number of spines in the first dorsal and first anal fins.

\section{Introduction}

The need for accurate definition and standardization in the use of biometric and meristic characters in systematic ichthyology has long been recognized (Ricker and Merriman, 1945). It is obvious that with the exception of truly self-explanatory characters, most measurements and counts must be defined in order to enable other workers to interpret the data. The need for standardization arises from the fact that in most cases, different methods (as applied to a given group), no matter how well defined, cannot be equalized for comparative purposes.

Owing to the high precision required, lack of definition and standardization of methods becomes quite a problem in the study of closely related species or infraspecific categories, and especially in the biometric analysis of populations where several independent workers using different methods may be working on the same group. Furthermore, the marked differences in structure existing among certain families of fishes usually prevent the application of a method to groups other than the one for which it was designed.

In recent years, the increasing interest in the biometric analysis of populations of tunas by various independent workers, has brought about the necessity to define and standardize the methods used in measuring and counting. The various methods which have been proposed are essentially in agreement (Godsil and Byers, 1944:125-129; Marr and Schaefer, 1949; Rivas, 1955) and have been successfully adopted by practically all workers in the field.

Also recently, new interest has developed in the taxonomy and population analysis of the sailfishes, spearfishes, marlins (Istiophoridae) and broadbill swordfish (Xiphiidae), a most confused group collectively known as "billfishes."

As far as can be ascertained, no formal methods of measuring and counting have ever been proposed for the billfishes. A survey of the literature shows that most of the methods used vary among the different workers and that lack of definitions renders the measurements and counts difficult or impossible to interpret. In addition, certain methods of measuring and counting employed in the past appear to be unsatisfactory and have resulted in questionable taxonomic interpretations.

For reasons already indicated above, the methods employed in the tunas cannot be applied to the billfishes. It is the purpose of the present paper to propose a series of measurements and counts for the latter group, based on previous field and laboratory experience as a result of studies conducted under sponsorship of the Charles F. Johnson Foundation. New characters not previously used in connection with billfishes are also included.

All the measurements described (excepting body girth) are straight-line distances and are made in metric units to the nearest millimeter, with slide calipers or dividers according to the size of the fish and the distance to be measured. (See also Godsil and Byers, 1944:125, and Marr and Schaefer. 1949:241, 242). In large fish, long measurements beyond the range encompassed by the larger calipers may be made with a steel tape graduated in metric units. For this purpose sliding metal or wooden arms similar to those used in the calipers should be attached to the tape, taking care that the tape remains straight during the measurement, with the arms perpendicular to it. As already pointed out by Morrow (1952:53,54), measurements taken with a tape alone are not satisfactory, since a straight line distance can seldom be obtained.

Also, in order to avoid error in the longitudinal measurements, the axis of the body should be maintained as straight as possible. This may be accomplished by placing the specimen on a flat surface and properly propping up the head, the caudal peduncle and the caudal fin. Although it is conventional in ichthyology to use the left side of the fish for the lateral

'Contribution No. 149 from the Marune Laboratory, University of Miami. This constitutes a technical report to the Charles F. Johnson Foundation.

${ }^{2}$ From Bulletin of Marine Science of the Gulf and Caribbean 6(1):18-27, 1956. Reprinted whth permission of editor. measurements, the best, or either side should be selected, according to the condition of the part to be measured. The jaws should be tied closed, especially in connection with measurements involving the tip of the mandible as a point of reference.

The numbers in the text for each measurement correspond to the numbers in the figure.

\section{Measurements}

1.-Body length.-A survey of the literature shows a great deal of inconsistency as to the selection of a body length in billfishes and lack of definition whereby the points of reference of this measurement can be accurately established. With very few exceptions, the instrument employed is not mentioned and there is no statement as to whether or not the measurement follows the curvature of the body (tape) or constitutes a straight-line distance (calipers or dividers).

It must be emphasized that since most, or all, other (relative) body measurements are referred to the body length as a base length, regardless of the method used in expressing proportions (ratios, regressions, etc.), this character must be defined with great care. It is obvious that if the base length is in error, all body proportions will also be in error regardless of how accurately the body parts may have been measured.

The "standard length" or "body length" for billfishes as used by most workers in the past does not seem to be satisfactory for various reasons. There has been agreement in the selection of the anterior end-point (tip of bill) but the posterior end point is variously interpreted as ". . . tail base" or " . mid-point of the peduncle ..." (Conrad and LaMonte, 1937, table 1 and p. $209)$; or " . . the midpoint of the shallowest vertical diameter of the caudal peduncle," (Gregory and Conrad, 1939:444), etc. Other workers offer no definitions or simply refer to "standard length" (deBuen, 1950:171) without further comment.

Despite lack of absolute standardization (Ricker and Merriman, 1945), most ichthyologists agree in that "standard length" is the straight line measurement taken between the tip of the snout and the middle of the caudal base, where the middle caudal ray joins the last (hypural) vertebra. In the billfishes, however, the middle of the caudal base cannot be determined without involved dissection, and the structure of the hypural vertebra and the caudal fin do not permit the determination of an accurate point of reference. Even after performing dissection, the point cannot be estimated from external form. For obvious reasons, the middle point on the posterior margin of the middle caudal rays (crotch of tail) constitutes a much better point of reference from the point of view of accuracy and convenience. In addition, the median caudal rays in billfishes are well protected by the upper and lower lobes of the fin, and are very seldom damaged.

As to the anterior point of reference, the tip, or a considerable portion of the distal end of the bill is frequently broken off, or the bill itself may be malformed and not attain its true length. For this reason, many otherwise valuable specimens have to be discarded or an inaccurate body length will result if the tip of the bill is used for the anterior point of reference. The mandible, on the other hand, is well protected by the bill and its tip is very seldom broken off or malformed.

In the light of the above discussion, it is therefore proposed that the body length in billfishes be measured between the tip of the mandible (with the jaws closed) and the middle point on the posterior margin of the middle caudal rays.

2.-Body girth. - Measured with a tape on one side of the body following its curvature from the uppermost point on the edge of the dorsal groove, vertical. ly to the edge of the pelvic groove (midline of belly in the swordfish); the resulting figure is then multiplied by two. This character, when expressed as a proportion of the base length, serves as a good indicator of the degree of robustness of the body.

3.-First predorsol length.-Measured from the tip of the mandible to the origin of the first dorsal fin. The latter point is the intersection of the anterior margin of the fin with the contour of the back when the fin is held erect.

4.- Second predarsal length.-Measured from the tip of the mandible to the origin (as defined above) of the second dorsal fin. The origin of the second dorsal is not as clearly defined as that of the first, and the point must be estimated as accurately as possible. Since this is a long measurement, the error. if any, is negligible.

5.-Prepectoral length.-Measured from the tip of the mandible to the origin of the pectoral fin. The origin of the pectoral fin is the intersection of its anterior basal margin with the side of the body, when the fin is held erect. 


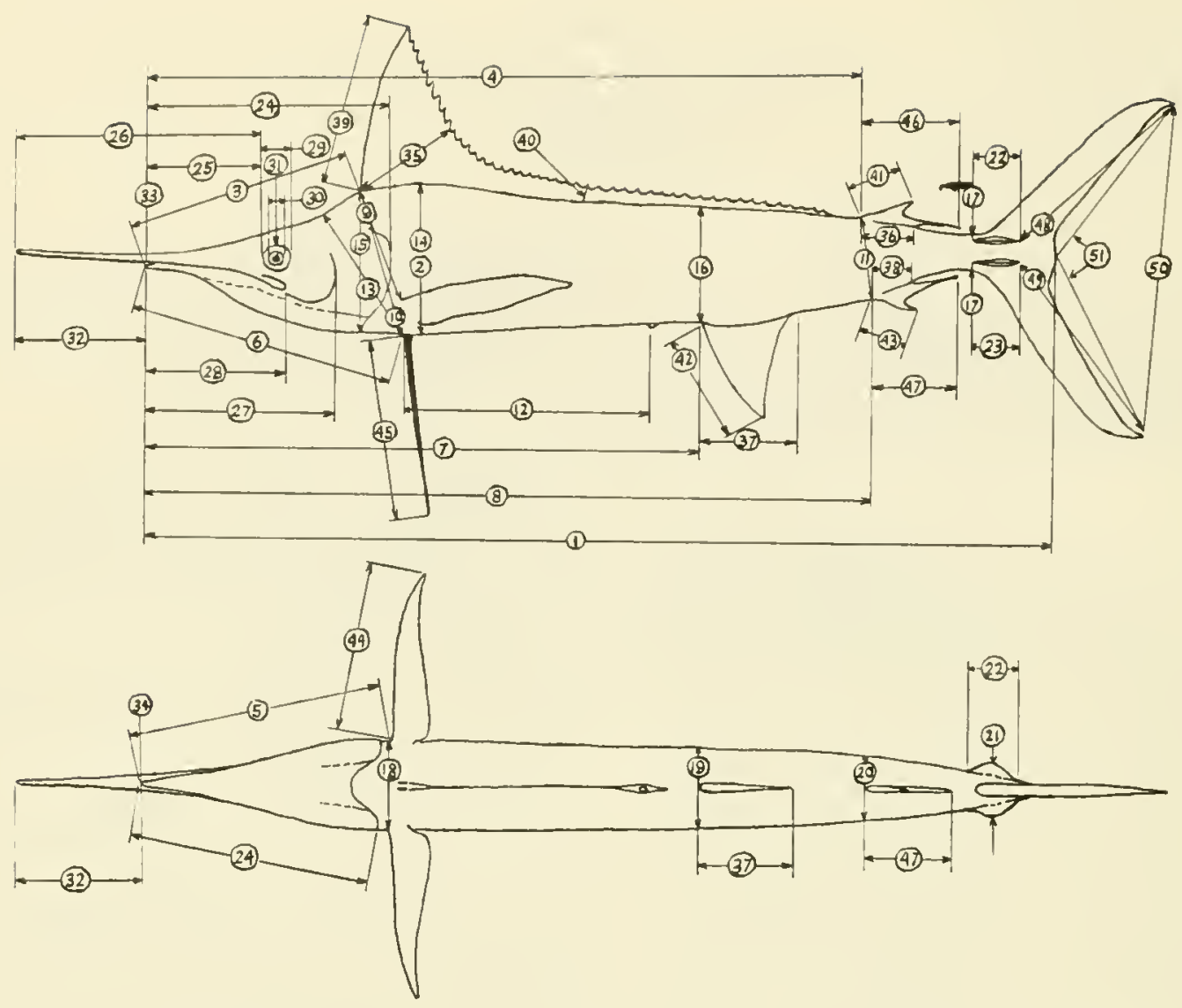

Figure 1.-Lateral and ventral views of a marlin, showing location of measurements. The numbers correspond to the numbers in the text.

6.-Prepelvic length.-Measured from the tip of the mandible to the origin of the pelvic fin. The latter point is the intersection of the anterior basal margin of the pelvic fin with the belly when the fin is held erect.

7.-First preanal length--Measured from the tip of the mandible to the origin of the first anal fin. The latter point is determined in the same manner as the origin of the first dorsel fin (See above).

8.- Second preanal length.-Measured from the tip of the mandible to the origin of the second anal fin. The latter point is determined in the same manner as the origin of the second dorsal fin (See above).

9.-Origin of first dorsal to origin of pectorol. -This character is selfexplanatory according to descriptions of these fin origins as given above (See first predorsal length and prepectoral length).

10.-Origin of first dorsal to origin of pelvic.-This character is selfexplanatory according to descriptions of these fin origins as given above (See first predorsal length and prepelvic length). It constitutes a good indicator of the anterior depth of the body.

11.-Origin of second dorsol to origin of second onal. - The character is self-explanatory according to descriptions of these fin origins as given above (See second predorsal length and second preanal length). It constitutes a good indicator of the posterior depth of the body.

12.-Origin of pelvic to vent. - Measured from the origin of the pelvic fin (See prepelvic length) to the anterior border of the anus.

13. - Origin of pelvic to nape. - Measured from the origin of the pelvic fin (See prepelvic length) to the nearest point on the midline of the nape. This character gives good quantitative expression of the "hump" associated with ontogenetic stages of certain species.

14.-Greotest depth of bodv. - This character is self-explanatory. Its points of reference correspond with those for body girth as described above.

15.-Depth of body at origin of first dorsal. - Measured from the origin of the first dorsal (See first predorsal length), vertically to the midline of the isthmus, not including the branchiostegal membrane if it extends to the latter point. This character is a good indicator of the posterior depth of the head and may be used in connection with origin of pelvic to nape. to obtain a quantitative interpretation of the magnitude of the "hump."
16.-Depth of body at origin of first onal-Measured from the origin of the first anal fin (See first preanal length), vertically to the edge of the dorsal groove. This character is a good indicator of the middle depth of the body.

17.-Leost depth of coudal peduncle.-Measured at the precaudal transverse grooves.

18. - Width of body at origin of pectorals. - Measured between the origins of both pectoral fins (see prepectoral length). This character is a good indicator of the anterior width of the body and may be more accurately and conveniently obtained with the fish hanging by the tail.

19. - Width of body at origin of first anal. - Measured at the widest point on the vertical from the origin of the first anal fin. This character is a good indicator of the middle width of the body and may be more accurately and con. veniently obtained with the fish hanging from the tail.

20. - Width of bodv ot origin of second onal. - Measured according to the same procedure described for the above character. This character is a good indicator of the posterior width of the body.

21. - Width of coudal peduncle at keel. - Measured between the outermost point on the edge of each caudal keel (swordfish). Upper caudal keels in sailfish, spearfish and marlin.

22.-Length of upper coudal keel-Measured between the points where the keel merges with the caudal peduncle anteriorly and with the caudal fin posteriorly. These points, although not well defined, may be estimated fairly accurately. Same procedure for single keel of awordfish.

23.-Length of lower coudal keel.-Measured according to the same procedure described above for the upper caudal keel.

24. - Heod length.-Measured from the tip of the mandible to the most distant point on the margin of the opercle.

25.-Snout length - Measured from the tip of the mandible to the most anterior point on the fleshy margin of the orbit.

26. - Bill length.-Measured from its tip to the most anterior point on the fleshy maryin of the orbit.

27.- Preopercular length. - Measured from the tip of the mandible to the most distant point on the margin of the preopercle.

28.-Maxillary length. - Measured from the tip of mandible to the posterior end of the maxillary. 
29. - Orbit diameter. - Measured as a horizontal distance from the most anterior point on the fleshy margin of the orbit.

30.-Iris diometer.-Measured as a horizontal distance from the most anterior point on the margin of the (ossified) sclera.

31.-Interorbital width.-Measured as the shortest distance between the uppermost point on the fleshy margin of the orbits.

32.- Tip of mandible to tip of bill.-This character is self-explanatory. Care must be taken that the jaws are well closed.

33.-Depth of bill.-Measured on the vertical passing through the tip of the mandible.

34.-W'idth of bill.-Measured on the vertical passing through the tip of the mandible.

35.-Origin of first dorsol to edge of fin.-Measured from the origin of the first dorsal fin (See first predorsal length) to the nearest tip (on dorsal edge) of a dorsal spine. This measurement is connection with the anterior height of the fin (see below) gives a good quantitative interpretation of the magnitude of the anterior dorsal lobe.

36.-Length of second dorsol bose. - Measured from the origin of the second dorsal fin (See second predorsal length) to the end of the fin base. The latter point is the intersection of the posterior basal margin of the last ray with the back.

37.- Length of first onal bose.-Measured from the origin of the first ana! fin (See first preanal length) to the end of the anal groove. To the last (very short) discernible spine in the swordfish.

38. - Length of second anal bose.-Measured according to the same procedure described above for the length of the second dorsal base.

39. - Anterior height of first dorsol.-Measured from the origin of the first dorsal fin (See first predorsal length) to the tip of the lobe.

40.-Length of middle dorsal spine. - The 25th dorsal spine measured (erect) from its intersection with the dorsal groove to its tip. This character is a good quantitative indicator of the ontogenetic changes in height undergone by the first dorsal fin

41.-Anterior height of second dorsal. - Measured from the origin of the secand dorsal fin (See second predorsal length) to the tip of its anterior lohe.

42.-Height of first anal.-Measured according to the same procedure described above for the anterior height of first dorsal.

43.-Anterior height of second onal-Measured according to the same procedure described above for the anterior height of second dorsal.

44.-Length of pectoral-Measured from the origin of the pectoral fin (See prepectoral length) to its tip, with the anterior basal margin of the fin perpendicular to the body.

45.-Length of pelvic-Measured according to the same procedure described above for the length of the pectoral. The fin should be held straight and stretched to its full length.

16.-Length of second dorsal.-Measured from the origin of the second dorsal fin (See second predorsal length) to the tip of the last (suctorial) ray held straight and against the middorsal line of the back.

47.-Length of second onal.-Measured according to the same procedure described above for the length of second dorsal.

48.-Length of upper caudal lobe.-Measured from the posterior end of the upper caudal keel to the tip of the upper caudal fin lobe.

49. - Length of lower caudal lobe.-Measured according to the same procedure described above for the length of upper caudal lobe, but using the end of the lower keel as point of reference.

50.-Caudal spread.-Measured between the tips of the caudal fin lobes.

51.-Coudal angle.-Measured by joining three points of reference represented by the tips of the caudal fin lobes and the middle point on the posterior margin of the middle caudal ray. This character is a good quantitative indicator of the change of angulation and concavity of the caudal fin among species and ontogenetically within a species.

\section{Counts}

1.-Dorsol spines. - The number of dorsal spines has not been widely used as a taxonomic character in billfishes and there is reason to believe that most of the few counts reported in the literature are not accurate.

Careful inspection of the anterior part of the dorsal fin will show that the first two or three spines are very close together, and therefore difficult or impossible to count without dissection. Very often the first and even the second spine is extremely short. They are easily missed if the skin covering is not peeled off to the base of the fin and the spines separated with the point of the knife. Posteriorly, and especially in adult marlins, the dorsal spines gradually decrease in length and become very short or obsolete as the second dorsal fin is approached. This condition appears to be correlated with growth, since in the post-larval and jurenile stages of billfishes (Beebe, 1941; Arata, 1954) the first dorsal fin is continuous with the second, but in the young adult stages a gap appears externally between these two fins. This gap becomes progressively longer as the fish becomes older and is quite extensive in very large specimens.

Dorsal spine counts in hillfishes without consideration of the above facts. would be inaccurate and lead to false taxonomic interpretations, when samples of widely differing age groups are compared. Dissection of the anterior part of the fin obviously should always be made, and posteriorly. attention should be paid to the magnitude of the gap and the resulting degree of external discontinuity between the first and second dorsal fins. If the distance between the last dorsal spine and the origin of the second dorsal fin is about equal to or somewhat greater than the distance between the last dorsa spine and the preceding one, no obsolete spines are then present. It is recommended that if the gap is of a magnitude indicating the existence of one or more obsolete spines the dorsal spine count be followed by the sign plus $(+)$

2.-Dorsal rays. - All rays are counted. In this fin the rays are easily made out without dissection.

3.-Anal spines.-Counted according to the same procedure described above for the dorsal spines. The discussion given above in connection with the dorsal spines also applies to the anal spines.

4.-Anal rays. - Same procedure as described above for the dorsal rays.

5.- Pectorol ray's. - All rays are counted. Although all rays are made out in this fin without dissection, care must be taken that the posterior part of the fin is well spread out so that the very small posterior rays are not missed.

\section{References}

ARATA, G. F., JR.

1954. A contribution to the life history of the swordfish, Xiphias gladius Linnaeus, from the south Atlantic coast of the United States and the Gulf of Mexico. Bull. Mar. Sci. Gulf and Caribbean, 4 (3):183-243, figs. $1-19$

BEEBE. W.

1941. A study of young sailfish (Istiophorus). Zoologica, N.Y., 26(20) 209-227, figs. 1-9, pls, 1-5.

BLEN, F. DE

1950. Contribuciones a la Ictiologia, III. La familia Istiophoridae y descripcion de una especie uruguaya (Makaira perezi de Buen). Publ. Cient. S.O.Y.P. Montevideo, (5):163-178, figs. $1-4$

CONRAD G. M. and F. LA MONTE

1937. Observations on the body form of the blue marlin (Mokaira nigri cans omplo, Poey). Bull. Amer. Mus. nat. Hist., 74 (4):207-220.

GODSIL, H. C. and R. D. B YeRs

1944. A systematic study of the Pacific tunas. California Div. Fish and Game, Fish Bull. (60):1-131, figs. 1-76.

Gregory, W. K. and G. M. CONRAD

1939. Body-forms of the Black marlin (Mokaira nigricans morlino) and Striped marlin (Makairo mitsukurii) of New Zealand and Australia. Bull. Amer. Mus, nat. Hist., 76 (8):443-456, figs. 1-2, pls. 3-6.

MARR, J. C and M. B. SCHAEFER

1949. Definitions of body dimensions used in describing tunas. Fish Bull. U.S., 51 (47):241-244, fig. 1

MORROW. J. E.. JR.

1952. Allometric growth in the striped marlin, Makaira mitsukuri, from New Zealand, Pacif. Sci., 6 (1):53-58.

RICKER. W. E and D. MERRIMAN

1945. On the methods of measuring fish. Copeia, (4):184-191.

RIVAS, L. R.

1955. A comparison between giant bluefin tuna (Thunnus thynnus) from the Straits of Florida and the Gulf of Maine, with reference to m1gration and population identity. Proc. Gulf \& Carib. Fish. Inst., 1954 (1955):133-149, fig. 1 


UNITED STATES

DEPARTMENT OF COMMERCE

NAT UNAL OCEANIC AND ATMOSPMERIC ADMINISTRATION

WATIONAL MAR NE FISHERIES SERVICE

SC ENTIE C PUBLICATIONS SIAFF

ROOM 450

1107 NE $45 T$ H ST

SEATTLE WA 98105

ORFICIAL BUSITSESS
FOURTH CLASS

POSTAGE AND FEES PAID US DEPARIMENT OF COMMERCE $\cos 210$

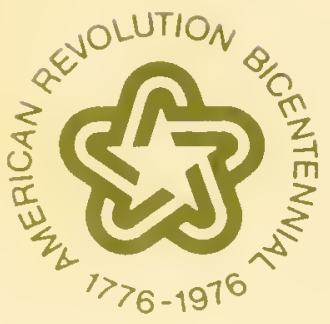

